Working Paper/Document de travail 2013-21

\title{
Why Do Emerging Markets Liberalize Capital Outflow Controls? Fiscal versus Net Capital Flow Concerns
}

by Joshua Aizenman and Gurnain Kaur Pasricha 
Bank of Canada Working Paper 2013-21

July 2013

\title{
Why Do Emerging Markets Liberalize Capital Outflow Controls? Fiscal versus Net Capital Flow Concerns
}

\author{
by \\ Joshua Aizenman $^{1}$ and Gurnain Kaur Pasricha ${ }^{2}$ \\ 1 USC and the NBER \\ Robert R. and Katheryn A. Dockson Chair in Economics and International Relations \\ Los Angeles, CA 90089 \\ aizenman@usc.edu \\ 2Financial Stability Department \\ Bank of Canada \\ Ottawa, Ontario, Canada K1A 0G9 \\ and \\ Santa Cruz Institute for International Economics \\ gpasricha@bankofcanada.ca
}

Bank of Canada working papers are theoretical or empirical works-in-progress on subjects in economics and finance. The views expressed in this paper are those of the authors.

No responsibility for them should be attributed to the Bank of Canada or the National Bureau of Economic Research. 


\section{Acknowledgements}

We would like to thank Jamshid Mavalwalla, Gagandeep Pabla and Derrick Schroeter for research assistance. We also thank Martin Bijsterbosch, Ian Christensen, Yothin Jinjarak, Rhys Mendes, Ila Patnaik, Brian Peterson, Subrata Sarker, Eric Santor and seminar participants at the Bank of Canada, December 2012 NIPFP-DEA Research Meetings and the January 2013 American Economic Association Meetings for useful comments and suggestions. 


\begin{abstract}
In this paper, we provide empirical evidence on the factors that motivated emerging economies to change their capital outflow controls in recent decades. Liberalization of capital outflow controls can allow emerging-market economies (EMEs) to reduce net capital inflow (NKI) pressures, but may cost their governments the fiscal revenues that external financial repression generates. Our results indicate that external repression revenues in EMEs declined substantially in the 2000s compared with the 1980s. In line with this decline in external repression revenues and their growth accelerations in the 2000s, concerns related to net capital inflows took predominance over fiscal concerns in the decisions to liberalize capital outflow controls. Overheating and foreign exchange valuation concerns arising from NKI pressures were important, but so were financial stability concerns and concerns about macroeconomic volatility. Emerging markets facing high volatility in net capital inflows and higher short-term balance-sheet exposures liberalized outflows less. Countries eased outflows more in response to higher appreciation pressures in the exchange market, stock market appreciation, real exchange rate volatility, net capital inflows and accumulation of reserves.

JEL classification: F32, G15

Bank classification: Debt management; Financial system regulation and policies; International topics; Recent economic and financial developments
\end{abstract}

\title{
Résumé
}

Les auteurs procèdent à une analyse empirique des facteurs qui ont poussé les pays émergents à assouplir leurs restrictions sur les sorties de capitaux ces dernières décennies. La libéralisation des flux sortants est un moyen pour les économies de marché émergentes de réduire la pression des entrées nettes de capitaux, mais elle prive l'État des recettes fiscales générées par la répression des flux financiers transfrontières. Les résultats montrent que les recettes tirées de cette répression ont diminué de façon marquée dans ces économies entre les années 1980 et 2000. Parallèlement à cette baisse et à l'accélération de la croissance des économies émergentes au cours des années 2000, les inquiétudes liées aux entrées nettes de capitaux l’ont emporté sur les aspects budgétaires dans la décision de libéraliser les sorties de capitaux. Les craintes que les volumes d'entrées nettes n'entraînent une surchauffe ou une surévaluation du taux de change ont pesé lourd, tout comme les enjeux de stabilité financière et les préoccupations quant à la volatilité macroéconomique. Les marchés émergents où les entrées nettes de capitaux étaient très variables et où les bilans étaient plus exposés à court terme ont moins libéralisé les sorties de capitaux. Les restrictions sur les flux sortants ont été davantage assouplies dans les pays dont la monnaie tendait à s’apprécier plus fortement, où la volatilité du taux de change réel et les entrées nettes de capitaux étaient plus élevées et où les marchés boursiers et les réserves de change progressaient plus rapidement.

Classification JEL : F32, G15

Classification de la Banque : Gestion de la dette; Réglementation et politiques relatives au système financier; Questions internationales; Évolution économique et financière récente 


\section{Introduction}

Recent years have seen a re-emergence of the policy debate on the appropriateness of capital controls. Opponents argue that capital controls can lead to local and global misallocation of resources, perpetuate global imbalances (by allowing countries to maintain undervalued real exchange rates) and encourage corruption. Further, they argue that in the empirical literature these controls have been found to be of limited effectiveness in stemming net capital inflows (NKI). Proponents argue that capital controls are macroprudential measures and an optimal response to distortions in financial markets (for example, herd behaviour, too-big-to-fail). These controls are deemed to be an important tool to prevent the buildup of financial sector risks and to reduce the damage associated with sudden stops. ${ }^{1}$ Adding fuel to the debate, the International Monetary Fund (IMF) has softened its longstanding opposition, now suggesting that capital controls may be a valid tool of macroeconomic and macroprudential management when other tools have been exhausted (IMF 2011a).

There are two key missing elements in the debate on what emerging-market economies (EMEs) should or should not do with regards to capital controls. The first is a fact-based analysis of the macroeconomic and financial pressures that EME policy-makers most often respond to when imposing capital controls. The empirical literature assessing emerging-market motivations for capital controls is scant. ${ }^{2}$ The second key missing element is a discussion of the use of capital outflow controls as a potential response to NKI pressures. Most of the recent policy debate has focused on tightening of capital inflow controls in response to surges in net capital inflows. ${ }^{3}$ However, because NKI are the difference between capital inflows and outflows, countries that have existing outflow controls have another potential tool to reduce NKI: the liberalization of outflows. ${ }^{4}$ This tool was discussed in the literature on managing capital flows of the 1990s (see Laban and Larrain 1997), but it has been missing from the recent debate. Recent research in Pasricha (2012) documents that, in 22 EMEs between 2004 and the onset of the 2008 financial crisis, outflow controls were liberalized more frequently than inflow controls were tightened. The pre-2008 crisis period saw a surge in net capital inflows to EMEs of a magnitude

\footnotetext{
1 “[South Korea’s] President Lee Myung-Bak, in an interview with the Financial Times published on Oct. 29, said any measures that the country may take to smooth cross-border capital flows should not be interpreted as capital controls but 'macro-prudential policies'.” (“Factbox - S. Korean Policymakers' remarks on capital controls,” Reuters, 10 November 2010.)

${ }^{2}$ Recent work by Fratzscher (2012) examines this question for overall capital account openness in a broad sample of emerging and advanced economies over the period 1984-2009. He finds that foreign exchange policy objectives and overheating concerns have been the two main motives for capital controls, particularly since 2000.

${ }^{3}$ See, for example, Ostry et al. (2011), Klein (2012), Hutchison et al. (2012), Patnaik and Shah (2012) and Warnock (2011).

${ }^{4}$ NKI are measured as the difference between inflows by non-residents and net outflows by residents. Therefore, both lower net inflows by non-residents and higher net outflows by residents would lead to a decline in NKI.
} 
comparable to the post-2008 crisis surge, yet inflow tightening measures became a primary tool of restricting NKI only after the crisis.

The use of outflow liberalization in NKI management policy can be constrained by the fact that outflow controls exist not only to manage capital flows but also to allow government to lower the cost of borrowing by keeping domestic savings at home. Sustained outflow controls often form part of a web of regulations on the domestic financial sector (for example, interest rate ceilings, high reserve requirements, directed lending) that constitute "financial repression." These regulations seek to further reduce the cost of government borrowing and to allocate savings to preferred sectors. Capital outflow controls help prevent capital flight in response to domestic regulations, and therefore are a key ingredient of financial repression. The revenues from financial repression can be substantial. Giovannini and de Melo (1993) show that for some 24 emerging and developing economies over the period 1972-87, revenues from external repression averaged $1.4 \%$ of GDP. These considerations suggest that the decision to liberalize outflow controls in response to surging inflows could involve weighing the benefits of reduced NKI against the loss of revenues from financial repression.

In this paper, we provide evidence on EME motivations for capital outflow policy by examining fiscal and macroeconomic factors at the time when outflow controls were liberalized. We address the two gaps in the literature identified above by focusing on capital outflow controls and by providing a positive analysis of outflow policy changes. To accomplish this, we build two novel datasets. First, we extend the dataset provided in Pasricha (2012) to cover the period 2001-10. This dataset comprises all changes in capital account regulations in 22 large EMEs and therefore provides a de jure assessment of capital controls. ${ }^{5}$ Second, we estimate the revenue from external financial repression which, following Giovannini and de Melo (1993), is defined as the fiscal revenue obtained by preventing residents from freely investing abroad. It is measured as the difference between the (effective or ex post) external and domestic interest rate on government debt, times the government's domestic debt.

Our updated Giovannini and de Melo measure of external repression revenues is available for 15 countries. ${ }^{6}$ We find that, in contrast to the 1980s, when many EMEs were found to be earning significant revenues from external repression, EMEs in the most recent decade earned negative (and statically insignificant) revenues from external repression, on average. The negative revenues mean that EME governments faced lower borrowing costs in foreign markets (even after accounting for costs imposed by exchange rate fluctuations) than in the domestic market. The decline in external repression revenues has occurred despite the fact that emerging

\footnotetext{
${ }^{5}$ A de jure assessment of policy measures the actual regulations in place, whereas a de facto assessment evaluates the impact of these regulations - for example, the presence of price differentials across markets or the volume of transactions.

${ }^{6}$ The 15 EMEs are Argentina, Brazil, Chile, China, Colombia, Egypt, India, Indonesia, Malaysia, Mexico, the Philippines, Peru, South Africa, Thailand and Turkey.
} 
economies continue to maintain significant restrictions on capital outflows (notwithstanding the liberalizations over time).

There are several possible interpretations of the negative external repression revenues found in our study. An EME government with positive revenues from repression may be reluctant to liberalize outflows to manage the concerns posed by surging NKI for fear of losing these revenues, but may find it easier to liberalize when there are no revenues to be lost. In fact, EMEs did liberalize outflow policy substantially in the 2000s. Most of the outflow liberalizations took place in the years of surging NKI (putting downward pressure on domestic interest rates) and rapid economic growth (leading to increasing fiscal revenues from other sources), which suggests that fiscal concerns did not pose a binding constraint for EMEs in this period. Another interpretation of the negative external repression revenues is that, while many of these EMEs could have borrowed even more in markets abroad in the last decade, they refrained from doing so. That they chose not to borrow more abroad even at favorable interest rates may reflect concerns about greater balance-sheet exposure (since most can borrow only in hard currencies) and the fear of a sudden stop. Finally, emerging markets may be willing to temporarily accept negative repression revenues to preserve the future repression tax base.

The result that concerns related to net capital inflows took predominance over fiscal concerns in the decision to liberalize capital outflow controls in the 2000s finds further support in our empirical exercise. EMEs liberalized outflow controls less when facing greater NKI volatility and higher short-term balance-sheet exposure, while they eased more when NKI, real exchange rate appreciation pressures and reserves accumulation were high - all pointing to concerns about foreign exchange valuation and domestic overheating. Unlike in the 1980s, we find that fiscal variables have very limited importance in explaining liberalization of capital outflow controls: only in the samples of relatively closed countries do we see a negative association of greater external repression revenues with easing of outflows. This lack of association is consistent with the decline in repression revenues for EMEs in the 2000s. That decade saw the growth accelerations of emerging markets, which led to a decline in their risk premia. The 2000s were also a decade of few adverse external shocks, real exchange rate appreciation pressures in EMEs and overall improved stances of their fiscal policies. Revenues from repression therefore became less important in the decision to liberalize outflows.

The paper is organized as follows: in the next section, we elaborate on the potential motivations for imposing capital outflow controls. Section III describes the construction of, and trends in, one of the main data series compiled in the paper - the changes in capital outflow controls. We devote section IV to describing the measures used to capture fiscal concerns, including the second main data series compiled in the paper: revenues from external repression. Section V identifies testable hypotheses and outlines the econometric methodology. Section VI reports the results and section VII concludes. 


\section{Potential Motivations for Capital Outflow Controls}

Many motivations have been advanced in the literature for imposing or liberalizing controls on outflows. ${ }^{7}$ Capital outflow controls have often been imposed, at least temporarily, in response to a run on the currency or inflation, sovereign debt and financial crises. However, outside of crisis periods, one of the principal motivations for sustaining capital outflow controls is that they allow governments to lower the domestic cost of borrowing for themselves and for their preferred sectors by keeping domestic savings at home. Further, controls on outflows facilitate the use of other measures constituting financial repression, such as interest rate ceilings and high reserves requirements, by preventing capital flight in response to these restrictions. This allows governments to further depress their borrowing costs. Giovannini and de Melo (1993) show that when countries face constraints on their ability to raise revenue through taxes, financial repression could be the optimal choice. They also show that for some 24 emerging and developing economies over the period 1972-87, revenues from external repression averaged about 9 per cent of total government revenue from taxes. The large magnitude of the revenues earned from maintaining outflow controls posed a potential major constraint toward liberalizations of the capital account. Outflow controls can also help governments maximize the inflation tax by limiting the ability of residents to shift to foreign assets. ${ }^{8}$ Aizenman and Guidotti (1994) argue that capital controls may be desirable in developing countries when collection costs associated with taxes (other than the inflation tax) are high.

Empirical work performed in the 1990s underscores the importance of fiscal policy as a motivation for imposing capital controls. Grilli and Milesi-Ferretti (1995) find that capital controls are associated with a higher ratio of government consumption to GDP, higher government revenues from seigniorage and lower real interest rates. Alesina et al. (1994) find that maintaining capital controls leads to a lower stock of government debt (presumably through lower debt service costs), and that countries with weaker central banks (and therefore lower resistance to the use of inflation tax) are more likely to be using capital controls. Recent work by Reinhart et al. (2011) also suggests that financial repression played an important role in the rapid reduction of public debts in advanced economies in the Bretton Woods era.

For countries that have legacy capital outflow controls (as was true of many emerging economies entering the new millennium), the decision on whether and when to liberalize these controls can be constrained by fiscal reasons discussed above, or by exogenous political factors, but can also be motivated by economic pressures. In particular, liberalization of capital controls can be motivated by their use as tools for managing macroeconomic and financial pressures arising from the size and volatility of net capital inflows. In periods of surges in net capital inflows,

\footnotetext{
${ }^{7}$ Capital controls include both controls on inflows by non-residents and controls on outflows by residents. Unless otherwise specified, we focus on controls on outflows by residents, briefly called outflow controls.

${ }^{8}$ See Dooley (1996) and Eichengreen (2001) for excellent surveys of the literature on these motivations.
} 
policy-makers may choose to either tighten controls on inflows or to liberalize controls on outflows in order to reduce the size and volatility of net capital inflows. The various concerns arising from rapid increases in NKI can be grouped into four main categories:

1. Concerns about overheating: Net capital inflows to emerging markets are often procyclical, increasing when the economies are booming and retreating when the economies are slowing (Kaminsky et al. 2005). Surging capital inflows in periods of high economic growth can therefore lead to overheating concerns by further boosting growth, domestic credit expansion and inflationary pressures.

2. Concerns about foreign exchange valuation: Net capital inflow surges can lead to overvaluation of the exchange rate, thus hurting export competitiveness.

3. Concerns about financial stability: NKI surges can exacerbate asset price booms in real estate or financial markets and aggregate balance-sheet exposures, thus giving rise to financial stability concerns.

4. Concerns about macroeconomic volatility: The booms and busts in non-residents' inflows can be an independent source of macroeconomic volatility and can exacerbate existing cycles.

Liberalizing capital outflow controls can address these concerns by opening a window for greater outflows, thus reducing the net capital inflows during boom times. Analogously, tightening of capital outflow controls can prevent capital flights in poor times. In addition, having resident investments abroad that can be liquidated and brought home at times of slowing economic growth can counter stops in inflows by non-residents, thus reducing overall volatility of net capital inflows. This channel has been shown to be historically important in mitigating the volatility of net capital inflows in high-income economies in recent studies of gross capital flows (Broner et al. 2011; IMF 2011b).

In this paper, we test the relative importance of the concerns described above, for 18 large emerging economies, over the period 2001-10. The testable hypotheses associated with each are described in section $\mathrm{V}$. The next section describes the evolution of capital controls in the last decade in these emerging markets.

\section{Evolution of Capital Controls Policy in the 2000s}

To analyze the motivation for liberalizing capital outflows, we use a unique dataset that contains changes in capital account regulation for 22 major EMEs between 2001 and 2010. This dataset is an expanded version of the data used in Pasricha (2012). The main source of data is the IMF Annual Report on Exchange Arrangements and Exchange Restrictions (AREAER). The AREAER provides information on member countries' exchange arrangements, exchange and trade restrictions and capital transactions. We focus on the capital transactions section, which 
includes relevant regulations applicable to the financial sector. AREAER information is supplemented with information on similar measures from central banks' and other country regulators' websites, as well as news sources and other research papers. ${ }^{9}$

The dataset provides information on the changes in capital controls, by date of effectiveness. We classify each change as representing an inflow or outflow control, an easing or a tightening of policy, and then count the number of inflow easings, inflow tightenings, outflow easings and outflow tightenings per quarter.

Our strategy of counting the number of measures is in line with the existing de jure measures of capital controls, which measure tightness of capital controls by summing (or using the principal components of) dummies that indicate the existence of regulations under broad categories of transactions (Edwards 2007; Chinn-Ito 2008; Schindler 2009). However, our strategy adds information in one or more dimensions to what is available in the existing indices: (i) the changes taking place within the broad categories considered by the indices, ${ }^{10}$ and (ii) the changes in capital controls applicable to inflows or outflows. The existing indices miss one or both dimensions. For example, of all the indices for which data are available for at least part of the 2000s, Schindler (2009) and Chinn-Ito (2008) do not take into account changes in the restrictiveness of controls. Further, the Chinn-Ito (2008) and Edwards (2007) indices do not distinguish between restrictions on inflows and outflows. ${ }^{11}$ The dataset used in this paper provides information both on the changes in controls under each category of transactions and on whether the restrictions relate to inflows (by non-residents) or outflows (by residents). ${ }^{12}$

The main demerit of this method of analysis is that the number of measures per se does not allow us to judge the impact of the measures (e.g., in terms of the volume of transactions it influences) or to differentiate the changes by their magnitude, which varies between countries. However, most measures in the database are of a relatively homogeneous magnitude, and therefore we

\footnotetext{
${ }^{9}$ Further information on the dataset is provided in Appendix A.

${ }^{10}$ The dataset categorizes changes as belonging to restrictions under the eight subcategories of capital transactions (for example, controls on capital and money market instruments, controls on direct investment), as described in Appendix A. If a major policy announcement includes several changes, each regarding a different category of transaction, each of these changes is counted individually. For example, on 14 March 2005, Brazil introduced three different changes: an elimination of the limit on investment in shares of the main company by employees of firms belonging to foreign groups; an elimination of the limit on remittances for outward foreign direct investment by nonfinancial private enterprises; and a removal of the authorization requirement for guarantees by non-financial judicial persons in credit operations for their foreign subsidiaries. Each of these changes is counted individually in our database.

${ }^{11}$ The Schindler (2009) index provides information on controls under different subcategories of transactions, for inflows and outflows separately, but the dataset covers only the period 1995-2005.

${ }^{12}$ However, our dataset does not allow a cross-country comparison of the existing level of de jure controls, unlike the other indices.
} 
think that our approach does provide useful information about the overall direction of policy, and about the attempts to liberalize or to close the capital account. ${ }^{13}$

The countries in the database include the 21 emerging markets that are in the MSCI Emerging Markets Index plus Argentina. However, for this paper, we drop the three Eastern Europe countries (the Czech Republic, Hungary and Poland), since their capital account liberalizations were determined by their European Union accession, rather than by any economic pressures. We also drop changes in Argentina before 2003, in order to include in the sample only relatively homogeneous or marginal changes in policy. We also drop Turkey before 2002Q2, to exclude its currency and inflation crisis period.

The emerging markets in the sample changed their capital controls 664 times between 2001 and 2010. Capital outflow controls saw 302 changes, and of these the majority (274) were easing of restrictions on outflows. There were 362 changes in inflow controls, of which a minority (135) were tightening of inflows. Outflow liberalizations were far more common than inflow tightenings in the sample.

Since countries could be easing and tightening restrictions on outflows (inflows) in the same quarter, to gauge the overall direction of policy we computed the following measures:

1. Net Easing of Outflows: This measure is the difference between the number of outfloweasing measures and the number of outflow-tightening measures in each quarter. We use this as our main dependent variable in this paper.

2. Net Tightening of Inflows: This measure is the difference between the number of inflowtightening measures and the number of inflow-easing measures in each quarter.

Further, since both outflow easings and inflow tightenings would tend to reduce the pressure of net capital inflows, we group the measures into whether they would encourage or discourage NKI; i.e., the difference between inflows and outflows, as in Pasricha (2012). This gives us the following additional categories:

3. NKI Reducing Measures: These are measures that represent tightening of inflows or easing of outflows.

4. NKI Increasing Measures: These are measures that represent easing of inflows or tightening of outflows.

5. $\quad$ Net NKI Restricting Measures $=$ NKI Reducing Measures - NKI Increasing Measures $=$ Net Easing of Outflows + Net Tightening of Inflows.

Figure 1 shows that net NKI restricting measures peaked in 2007 and again in 2010, both peak years for net capital inflow pressures to EMEs. It also shows that in 2007, EMEs as a whole were liberalizing rather than tightening controls on inflows, and that outflow liberalizations were the

\footnotetext{
${ }^{13}$ Appendix Table A.2 in Pasricha (2012) provides a list of measures taken by EMEs in 2010, which attests to their small magnitude.
} 
predominant tool for restricting NKI in the 2007 peak. Only in 2010 did the EME stance on inflows policy become a net tightening stance and complement the NKI reducing stance on outflows policy. ${ }^{14}$

\section{Figure 1: Net Outflow Easings Peaked in 2007, along with Net Capital Inflows}

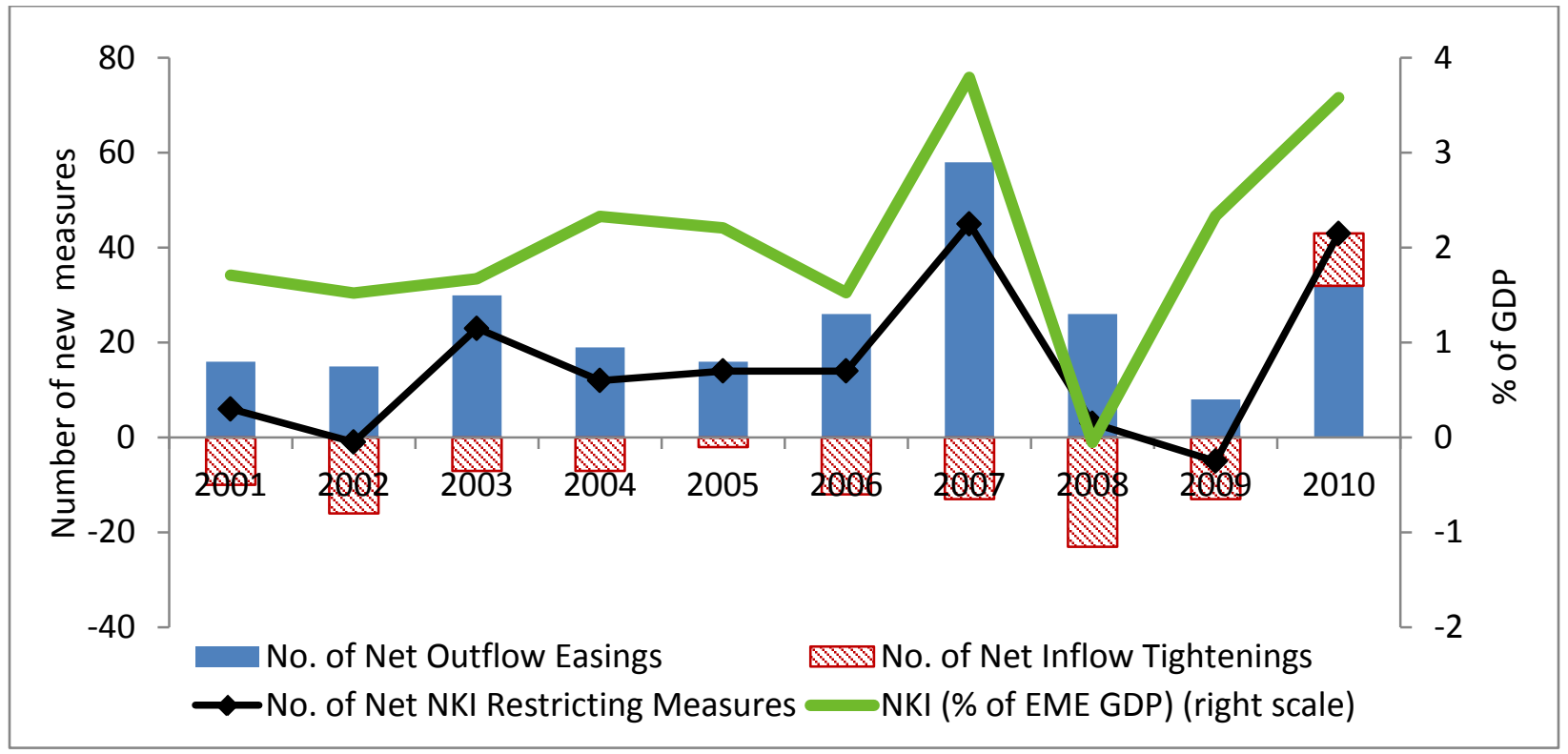

Notes: Net capital inflows/GDP is the unweighted sum of NKI to the 18 EMEs in the sample divided by the unweighted sum of their nominal GDPs. Net outflow easings are the number of easings of outflows less the number of tightening of outflows. Net NKI restricting measures are the sum of net outflow easings and net inflow tightenings.

There were important differences between countries in terms of the degree of activism on the capital account (Figure 2). India and Thailand were the most active, introducing more than 50 NKI reducing measures over the sample period, whereas Indonesia, Egypt and Morocco were the least active in changing capital account policy. There were also differences between countries in terms of the extent to which they relied on tightening of inflow controls or easing of outflow controls as NKI reducing measures. Malaysia, Morocco and Chile relied exclusively on easing of outflows, whereas Indonesia, Peru, Brazil and Colombia largely used inflow-tightening measures.

The propensity to change capital outflow controls could be associated with the monetary policy framework and by flexibility of the exchange rate regime of countries (Table 1). EMEs with inflation-targeting (IT) monetary policy and freely floating exchange rates on the whole took fewer measures and changed policy less frequently. The last two columns of Table 1 show that a regime with freely floating exchange rates introduced an average of 0.51 measures per quarter,

\footnotetext{
${ }^{14}$ The figure sums net inflow tightening measures over all EMEs so that net inflow tightening in one country could be cancelled by net inflow easing in another. However, the conclusion that EMEs were liberalizing outflows more than they were tightening inflows remains even if one looks only at NKI reducing measures; i.e., inflow tightenings in all countries and outflow easings in all countries only. As noted above, there were far more outflow easings than inflow tightenings in the sample period.
} 
out of which 0.38 measures were NKI reducing measures. This compares to non-freely floating exchange rate regimes, a member of which, on average, introduced 1.16 measures per quarter, out of which 0.68 measures were NKI reducing measures. The statistics for non-freely floating regimes are very similar to those for non-inflation-targeting monetary policy regimes. An IT monetary policy regime introduced an average of 0.72 measures per quarter, out of which 0.53 measures were NKI reducing measures. For all country groups, outflow easings were the majority of NKI reducing measures. However, in contrast to freely floating exchange rate regimes, IT regimes relied relatively less on outflow-easing measures and more on inflowtightening measures: 38\% of NKI reducing measures introduced by IT regimes were inflow tightenings, compared to $16 \%$ of NKI reducing measures introduced by freely floating exchange rate regimes.

Figure 2: Some EMEs Were More Active than Others in Introducing NKI Reducing Measures

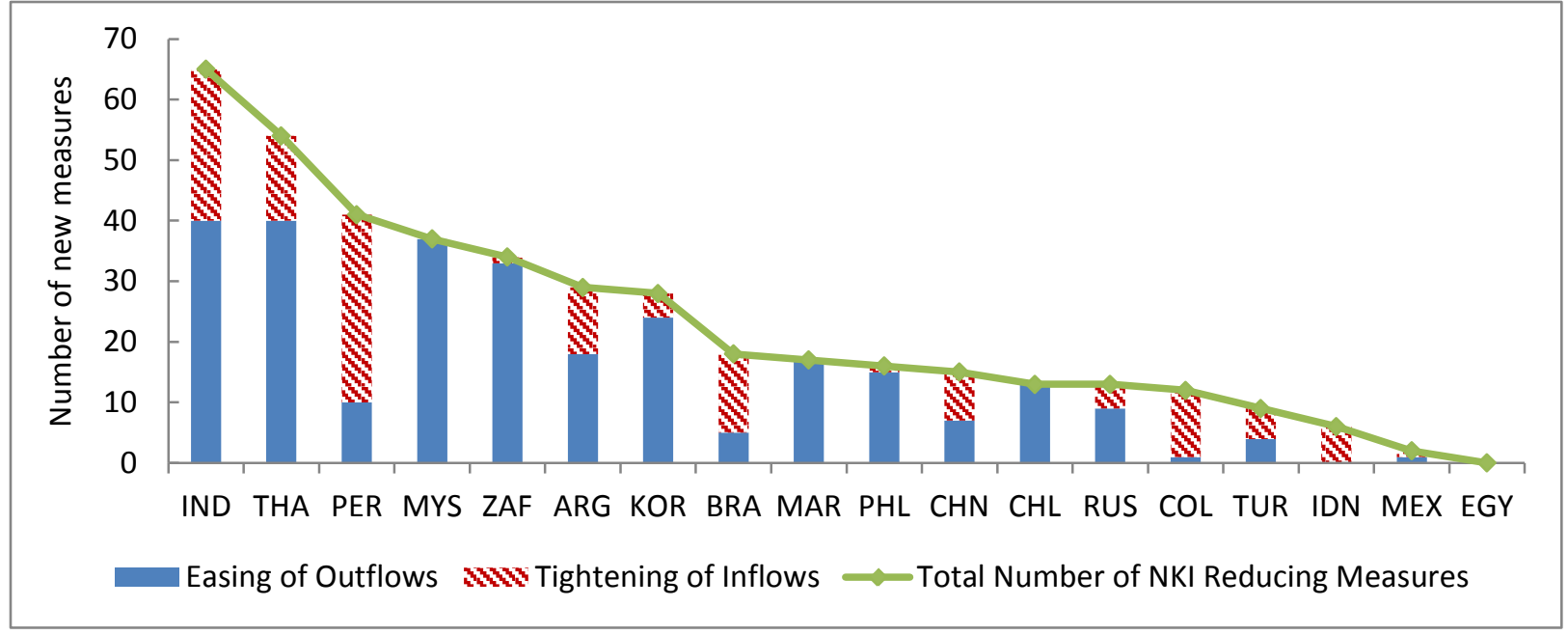

Notes: NKI reducing measures are the sum of outflow easings and inflow tightenings. The number of measures is the total over the period 2001-10 (except for Argentina and Turkey, as noted in the text).

In the following sections, we ask whether the frequency and timing of the net liberalizations of outflows was contingent on fiscal, macroeconomic and financial pressures in the economy in question, focusing on the fiscal revenues that the governments were obtaining from external financial repression.

\section{Measures of Fiscal Concerns}

To capture the extent to which lost fiscal revenues would constrain the removal of capital outflow controls, we deploy several measures of fiscal concerns. The first and the most direct measure of the contribution of outflow controls to fiscal revenues is the revenue from external repression, which we describe in the next subsection. The other measures of fiscal concerns, 
described in subsection IV.B, seek to capture the fiscal space of the government as well as the revenue from the use of internal repression that capital outflow controls facilitate.

\section{A. External repression revenues in EMEs}

The main purpose of capital outflow controls is to keep the domestic cost of borrowing for the government below the rate that would prevail in a fully integrated economy. Therefore, external repression revenue can be defined as the additional cost that the government would have to bear to service its domestic debt in the absence of outflow controls. Thus defined, external repression revenue can be measured as the difference between the effective interest rate on the government's foreign borrowing less the effective interest rate paid by the government on domestic borrowing, times the repression tax base, which is the government's domestic debt (Giovannini and de Melo 1993).

The domestic interest rate is computed as

$$
i_{t}=\frac{\text { Interest Payments on Domestic Debt }}{\text { (Domestic Debt Outstanding } \left._{t}+\text { Domestic Debt Outstanding } \text { Dom-1 }_{t}\right) / 2}
$$

where interest payments and debt outstanding are measured in local currency units (LCU). ${ }^{15}$

The effective external interest rate on government debt has two components: the nominal (U.S.) dollar interest rate on foreign debt and the foreign exchange component (i.e., the increase in dollar interest payments due to depreciation of the domestic currency against the dollar). These components are defined as follows.

\section{Nominal dollar interest rate on external debt}

This is computed as the nominal dollar interest payments, including increases in interest arrears, divided by the average outstanding external debt measured in U.S. dollars (USD):

$$
i^{*}=\frac{\text { Interest Payments }(U S D)_{t}+\text { Change in Interest Arrears }(U S D)_{t}}{\left(\text { Debt Outstanding }(U S D)_{t}+\text { Debt Outstanding }(U S D)_{t-1}\right) / 2} .
$$

The nominal dollar interest rate is computed on non-concessional public and publically guaranteed (PPG) external debt from private creditors. ${ }^{16}$

\footnotetext{
${ }^{15}$ The formulas provided in the text are for annual data. For quarterly data, the interest rate is annualized by multiplying the right-hand side of the above formula by 4 . All interest rates are expressed as per cent per annum. Full details on the data and construction of external repression revenues are provided in Appendix B.

${ }^{16}$ However, interest arrears were available only for total debt from private creditors (including non-PPG debt) and on total PPG debt (including bilateral and multilateral concessional debt). In all cases, the arrears on total PPG debt were higher than arrears on total debt from private creditors. Therefore, as an approximation, we use the arrears from total debt from private creditors. Arrears refer to interest accrued (and due) but not paid.
} 


\section{Foreign Exchange (FX) component}

The foreign exchange component is computed as the percentage depreciation of the average annual exchange rate times the nominal dollar interest rate on external debt, and captures the increase in interest payments in dollars due to depreciation of the domestic currency against the U.S. dollar:

\section{$F X$ component $=i^{*}$. (Percent Depreciation of LCU/USD exchange rate $)$.}

The effective external interest rate is computed as the sum of the above two components.

In principle, there is a third component of effective interest rate on external debt: the "debt revaluation cost." This cost consists of two elements: (i) the change in the local currency value of the stock of external dollar-denominated debt due to the change in the value of local currency against the dollar, and (ii) the U.S.-dollar revaluation cost, defined as the increase in dollar value of debt outstanding (repayable) due to appreciation of the dollar against the currencies of denomination of external debt. Debt revaluation cost represents accrued costs and is amortized over the duration of the loan, rather than over the course of a single year. In this paper, our base measure of repression revenues includes only the nominal dollar interest rate and the FX component. While we also compute the debt revaluation cost (and provide summary statistics on the repression revenues including it), we do not include it in our base measure of external repression revenues - without knowing the maturity of the debt and the repayment schedule, we would add a very large and volatile component to the repression revenues by including the debt revaluation cost. ${ }^{17}$

Another key area in which our measure differs from Giovannini and de Melo is that they use only central government external and domestic interest commitments. Due to data constraints, we use PPG debt for the external interest rate, and the broadest level of government for which data are available for the domestic interest rate. Since central government debt usually carries the lowest risk premium, the use of interest on PPG debt would tend to inflate our estimates of repression revenues. However, as we will show below, even at these inflated levels, for most EMEs in our sample period, the repression revenues were in fact negative, in contrast to Giovannini and de Melo.

\section{Trends in external repression revenues}

The median external repression revenues in the 2000s for 8 of the 15 countries for which we had data were negative (Figure 3). For another three countries, the median revenue as a percentage of GDP was less than $0.5 \%$ of GDP. The mean repression revenues for all countries during the

\footnotetext{
${ }^{17}$ When Giovannini and de Melo (1993) computed repression revenues, the U.S.-dollar revaluation component was very small, since most external debt of emerging markets was denominated in U.S. dollars. In our sample, the U.S.dollar revaluation component turns out to be large and volatile. This may be due to changes in currency composition of external debt of EMEs, but also due to greater flexibility of their exchange rates.
} 
2000s were $-0.19 \%$ of GDP (Figure 4). These represent significant declines from the 1980s, when Giovannini and de Melo estimate the average revenue to be about $1.4 \%$ of GDP. ${ }^{18}$

Figure 3: Median External Repression Revenues, 2000s (\% of GDP)

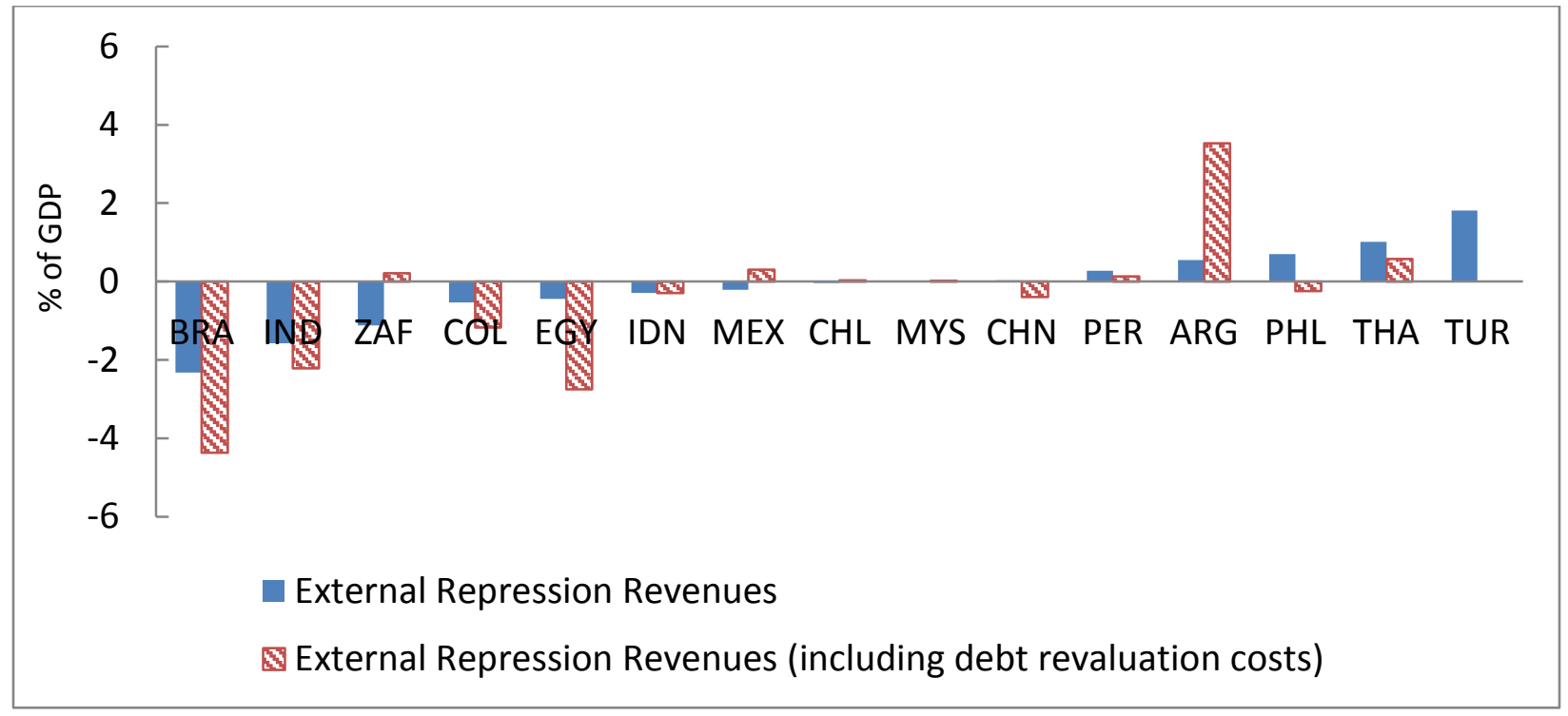

Figure 4: Mean External Repression Revenues, \% of GDP

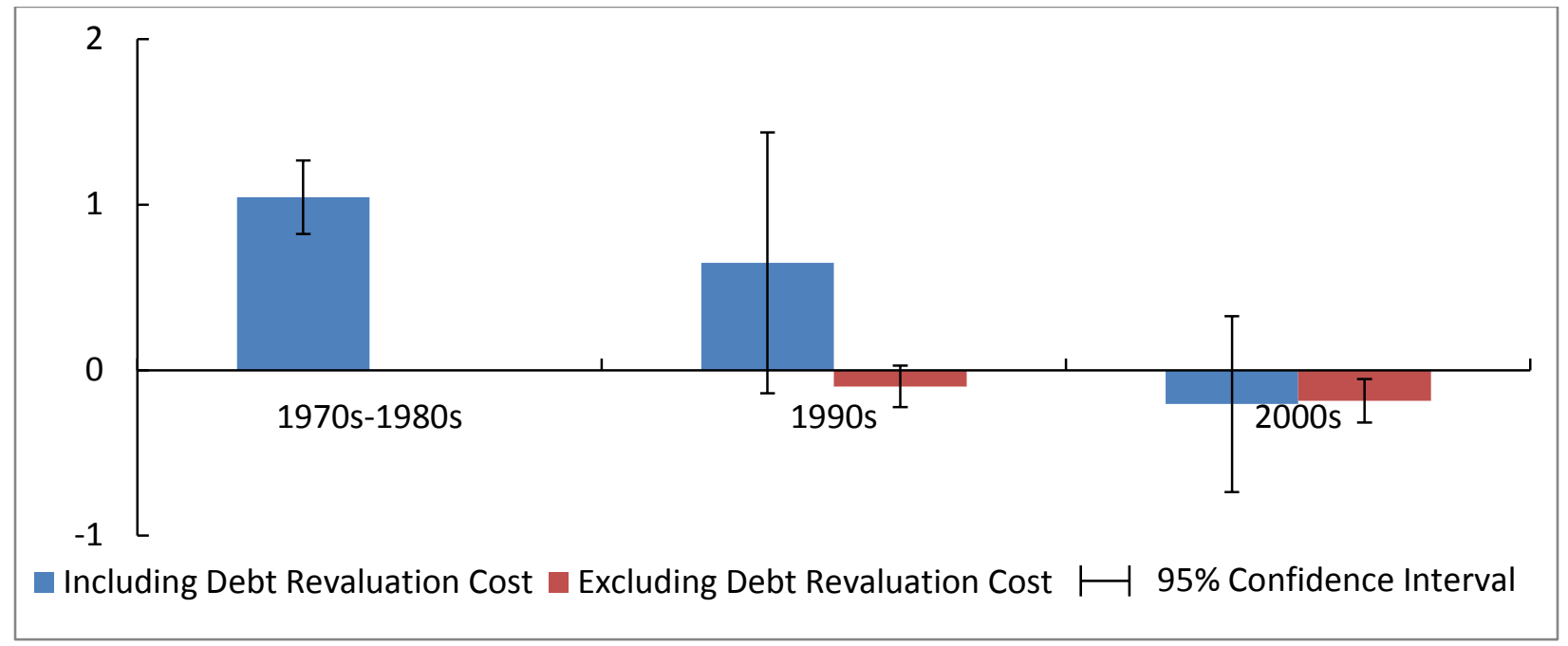

Notes: The 1980s mean is from Giovannini and de Melo (1993) and covers the countries in their sample that overlap with ours. The 1980s values are, in fact, over those years between 1974 and 1987 for which the Giovannini and de Melo estimates are available. The 1990s estimates are for the years 1995-99, or the years for which data for each country are available.

\footnotetext{
${ }^{18}$ Note that the average revenues of $1.4 \%$ of GDP mentioned in the introduction are for all the EMEs in Giovannini and de Melo's sample. Figure 4 averages over the part of their sample that overlaps with ours. Repression revenues including debt revaluation costs include the effect of exchange rate changes on the value of principal in the effective external interest rate. Repression revenues excluding debt revaluation costs incorporate only the impact of exchange rate changes on interest payable in computing the effective external interest rate.
} 


\section{Why have external repression revenues declined?}

Most of the difference between the external effective and domestic interest rate in the 2000s is due to the difference between the external dollar interest rate and the domestic interest rate (Figures 5 and 6). In contrast to the 1980s, the FX component is a small part of effective interest rate differentials for most EMEs. The decline in the external repression revenues therefore reflects both the decline in the external dollar interest rate and the decline in the FX component.

Figure 5: Exchange Rate Component of External Repression Revenues Is Small for Most Countries

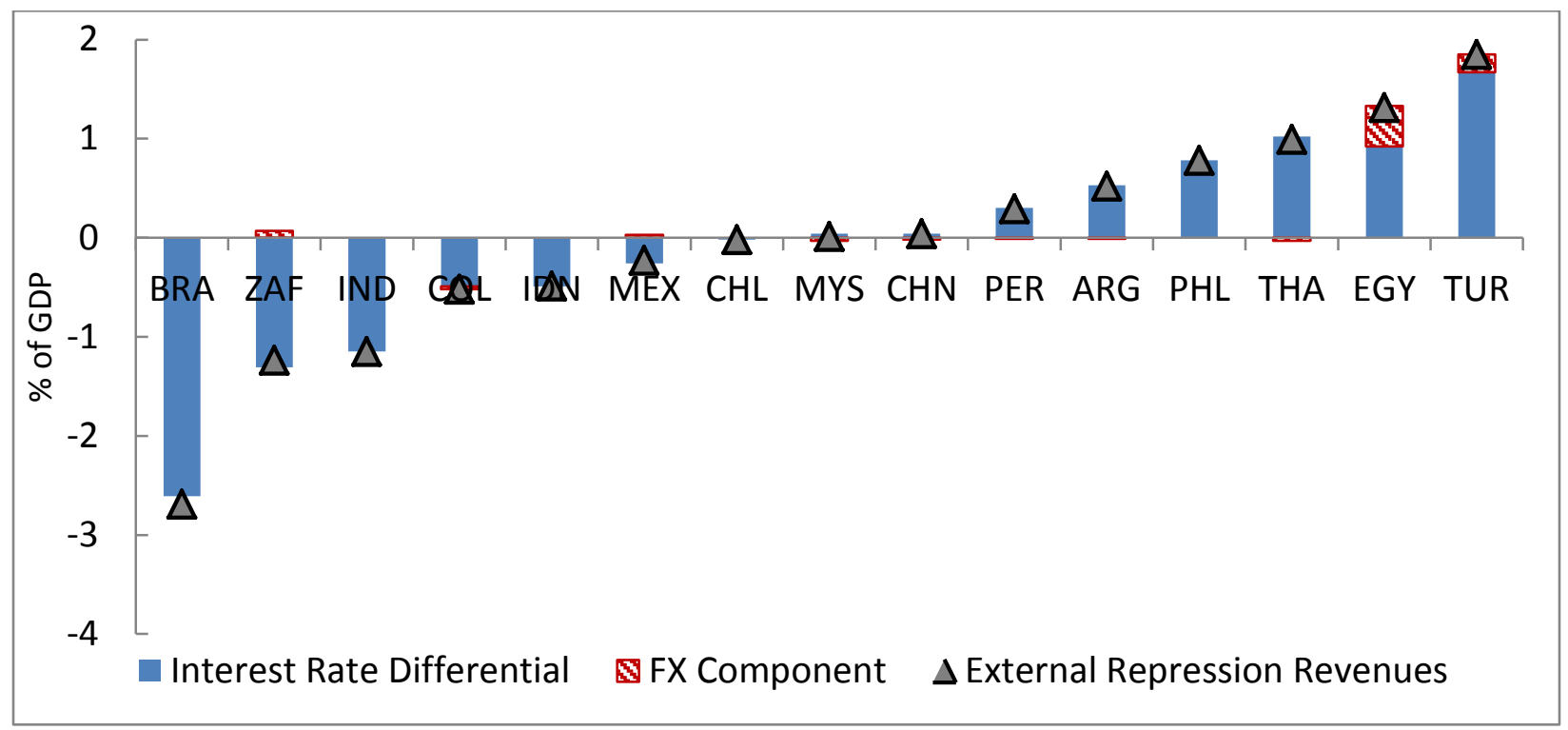

Notes: The plotted values are the means of the variables for the 2000s for each country. Interest rate differential refers to the percentage difference in external dollar and domestic interest rates. FX component is the percentage exchange rate depreciation against the U.S. dollar times the external dollar interest rate. All variables are expressed as per cent per annum.

Several factors can explain the decline in the two components of external repression revenues, many of them related to the growth accelerations of EMEs in the 2000s (in comparison to the 1970s-80s). The relatively strong growth performance of EMEs vis-à-vis the rest of the world in that period, in combination with the easing of monetary policy in the advanced economies, led to an overall decline in their external risk premia. Strong domestic demand growth and a shortage of capital in EMEs drove up domestic interest rates, and this effect could not fully be counteracted by net capital inflows (given remaining restrictions on these inflows). It also led to a real exchange rate appreciation trend, which contributed to the decline in the FX component. 
Figure 6: Components of Repression Revenues - BRICS

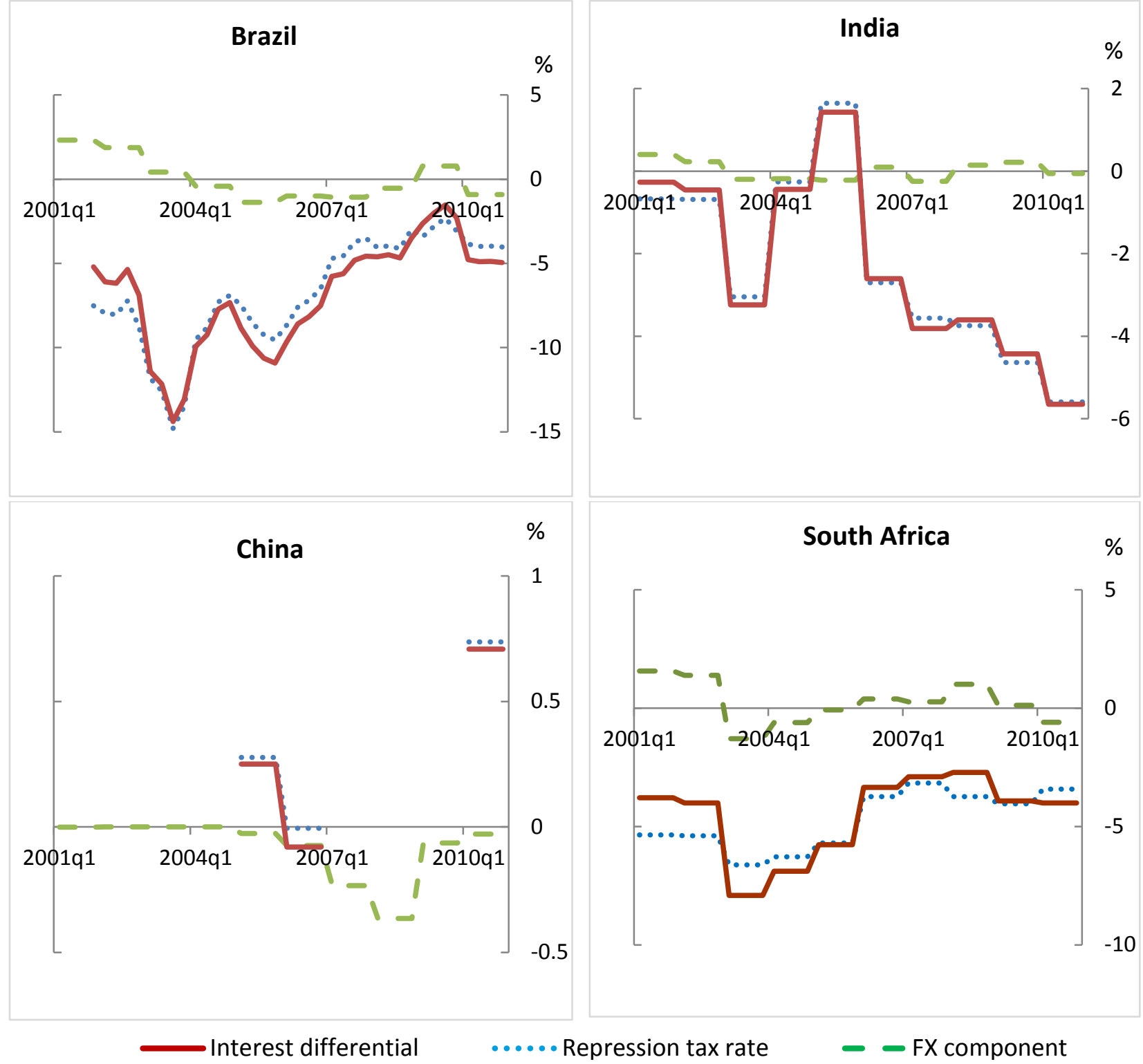

Notes: "Interest Diffl." refers to the percentage difference in external dollar and domestic interest rates. FX component is the percentage exchange rate depreciation against the U.S. dollar times the external dollar interest rate. All variables are expressed as per cent per annum.

There are two other possible reasons for the low estimates of external repression revenues. First, it is possible that in a period of strong EME growth, the external risk premia may have declined too much. History suggests that just as the European periphery debt was overvalued in the years after the launch of the euro, it may be the case that EME external debt may seem overvalued in the 2000s in posterity. Second, our measure assumes that the external interest rate represents the "market interest rate" for government debt that would prevail in the absence of outflow controls. This assumption ignores the fact that several EME governments, particularly India and China, raise a very small share of their total debt (if any) in markets abroad. As a result of the pervasive 
internal financial repression measures, they are able to finance their borrowing needs largely domestically, without pushing up interest rates on their debt and their debt burdens. Therefore, the market interest rate they would face in the absence of external repression could be substantially underestimated by the prevailing external interest rate, since the governments' fiscal positions would look less sustainable and the risk premium on government debt would be higher in the absence of these restrictions (the demand curves the governments face would be steeper).

\section{Interpretations of negative repression revenues}

There are several possible interpretations of the negative external repression revenues found in our study. Liberalization of outflows by EMEs with negative external repression revenues (other things being equal) could, in theory, lead to a further increase in their domestic interest rate over the external rate. An EME government concerned about the cost of servicing the domestic debt would do one of the following: (1) not liberalize outflows, (2) liberalize outflows in tandem with liberalizing inflows, or (3) borrow more in markets abroad (liberalizing inflows only for itself). In practice, the fiscal concerns did not prevent outflow liberalizations - EMEs did liberalize outflow policy substantially in the 2000s. However, this was made possible by surging inflows, since most of the liberalizations took place in the years of high NKI (putting downward pressure on domestic interest rates) and rapid economic growth (leading to increasing fiscal revenues from other sources). This suggests that fiscal concerns did not pose a binding constraint to outflow liberalization in the 2000s.

A possible interpretation of the negative external repression revenues is that, while many of these EMEs could have borrowed even more in markets abroad in the last decade, they refrained from doing so. That they chose not to borrow more abroad even at favorable interest rates may reflect concerns about greater balance-sheet exposure (since most can borrow only in hard currencies) and the fear of a sudden stop. In the event of a sudden stop and the associated sharp exchange rate depreciation, EMEs with larger external debt denominated in foreign currencies would experience a sharper increase in the cost of servicing the debt, and more limited external debt refinancing opportunities. The challenges faced by South Korea and Mexico during the 2008-09 crisis would reinforce the concerns about the risks of sudden stops in bad times even in relatively developed EMEs. ${ }^{19}$ Finally, emerging markets may be reluctant to open the door more widely to capital outflows to preserve the future repression tax base.

\footnotetext{
${ }^{19}$ These considerations also suggest that a drawback of the Giovannini and de Melo (1993) financial repression measure is focusing on the first moment (expected interest rate-cum-exchange rate depreciation), overlooking the second moment (exposure to future volatility associated with costly external debt refinancing during times of crisis).
} 


\section{B. Other measures of fiscal concerns in EMEs}

Being a measure of external repression, our measure of financial repression does not take into account the revenues that internal financial repression measures (interest rate controls, directed credit, high reserve requirements, etc., which would be ineffective without capital controls) generate for the government. That is to say, our measure of repression does not measure the extent to which the domestic interest rate is below the domestic rate that would prevail in the absence of internal repression (and in the presence of capital controls). In addition, it does not take into account the seigniorage tax revenue, the savings to the government from sterilization and the costs imposed on households that accrue to corporations or banks, rather than to the governments. Recent literature suggests that the size of implicit taxes generated via the banking sector in EMEs can be substantial. According to Lardy (2008),

"The People's Bank of China controls interest rates in a way that has led to significant financial repression-low and now negative real return on deposits-as inflation has risen in recent years. This distorted interest rate structure is a significant obstacle to further reform of the financial system and to sustaining China's rapid economic growth. Financial repression costs Chinese households about 255 billion renminbi (US\$36 billion), 4.1 percent of China's GDP, and a fifth of it goes to corporations, one-quarter to banks, and the government assumes the rest."

To capture some of the contribution to fiscal policy of internal repression revenues, we use several measures of fiscal space and of internal repression. These include:

1. Measures of fiscal space:

a. Fiscal balance as a share of government tax revenues

b. Gross government debt as a share of government tax revenues

2. Measures of fiscal internal repression revenues:

a. Liquidation tax (negative of the real interest rate on domestic government debt)

b. Real deposit interest rate on domestic government debt

c. Banking sector net lending to government as a share of banking sector assets*Inflation. This measure captures the extent to which the government is able to allocate banking savings to itself and tax it through inflation.

Consistent with the decline in external repression revenues, measures of fiscal space and of internal repression revenues in EMEs have also improved over time. Government debt has declined as a percentage of tax revenues and the fiscal balance has improved substantially, potentially allowing the governments room to liberalize outflow controls (Figure 7). The inflation tax the governments obtained from captive lending to it by the banking sectors has also declined substantially between the 1990s and 2000s (Figure 8). The real deposit interest rate on banking sector deposits has been positive, on average, during both the 1990s and 2000s, and governments have been paying positive real interest rates on their domestic debt (implying negative liquidation taxes). 
The fact that EME growth was stronger and less volatile in the 2000s may have also led to a lesser need for repression revenues. Indeed, the average tax-GDP ratios for EMEs increased by 2 percentage points to $15.2 \%$ of GDP in the 2000s from the 1990s (Figure 9). ${ }^{20}$

Figure 7: Mean Gross Government Debt and Fiscal Balance, \% of Tax Revenues

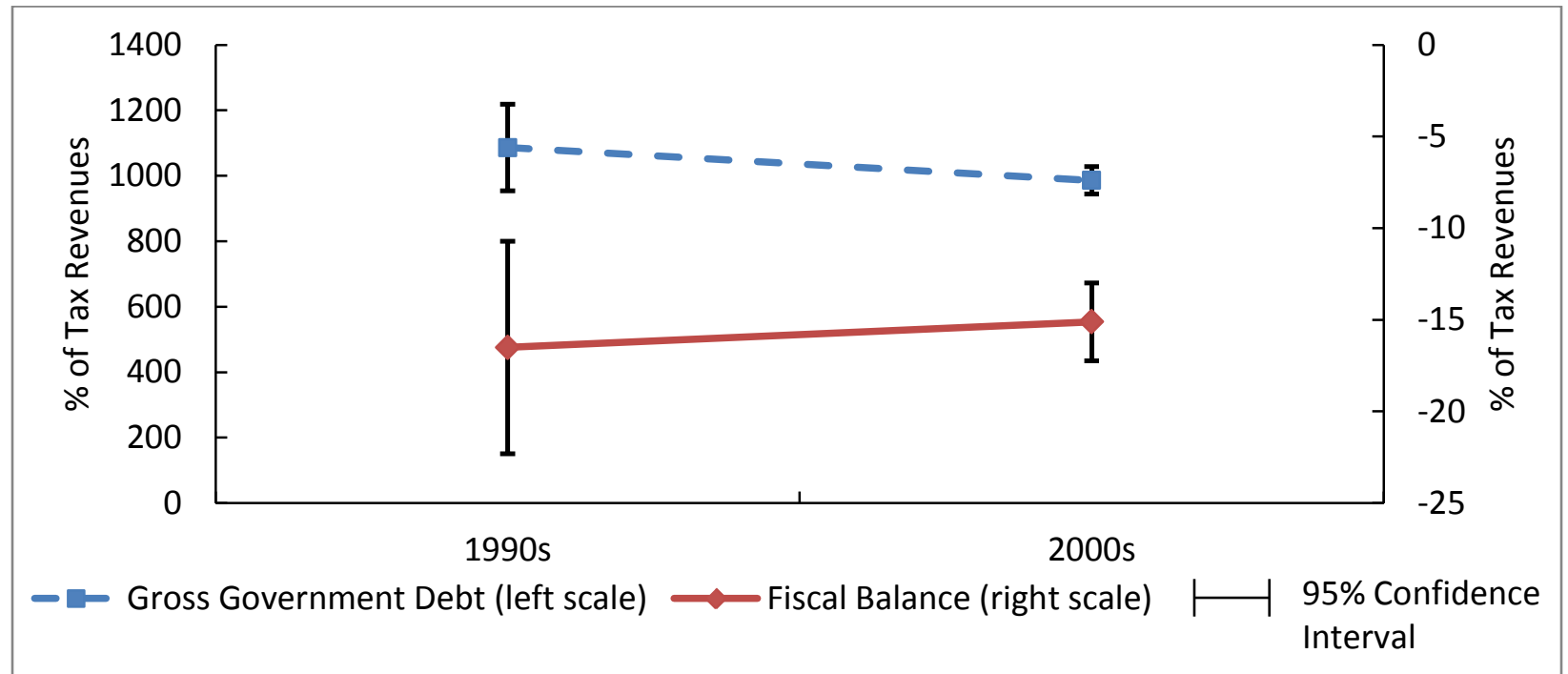

Note: The plotted values are mean for all EMEs in the decade and the 95\% confidence interval around the mean.

\section{Figure 8: Measures of Internal Financial Repression}

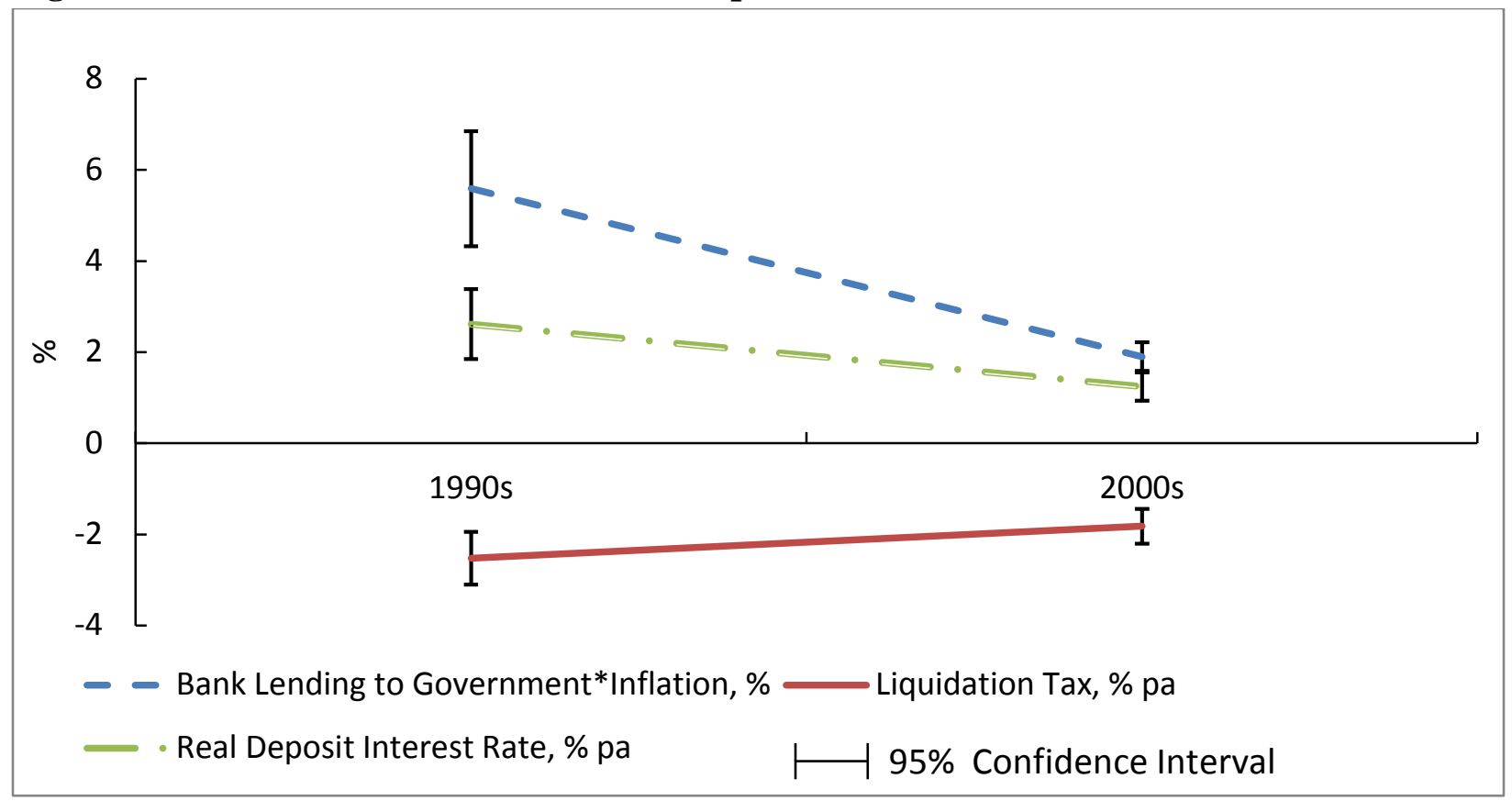

Note: The plotted values are mean for all EMEs in the decade and the 95\% confidence interval around the mean.

\footnotetext{
${ }^{20}$ Among the intriguing developments has been the relative decline in the role of "easy taxes to collect" (such as tariff and inflation taxes), and the rise of the role of value-added taxes (see Aizenman and Jinjarak 2009; Bird and Gendron 2011).
} 
Figure 9: Mean Tax-GDP Ratio for EMEs Has Improved Over Time

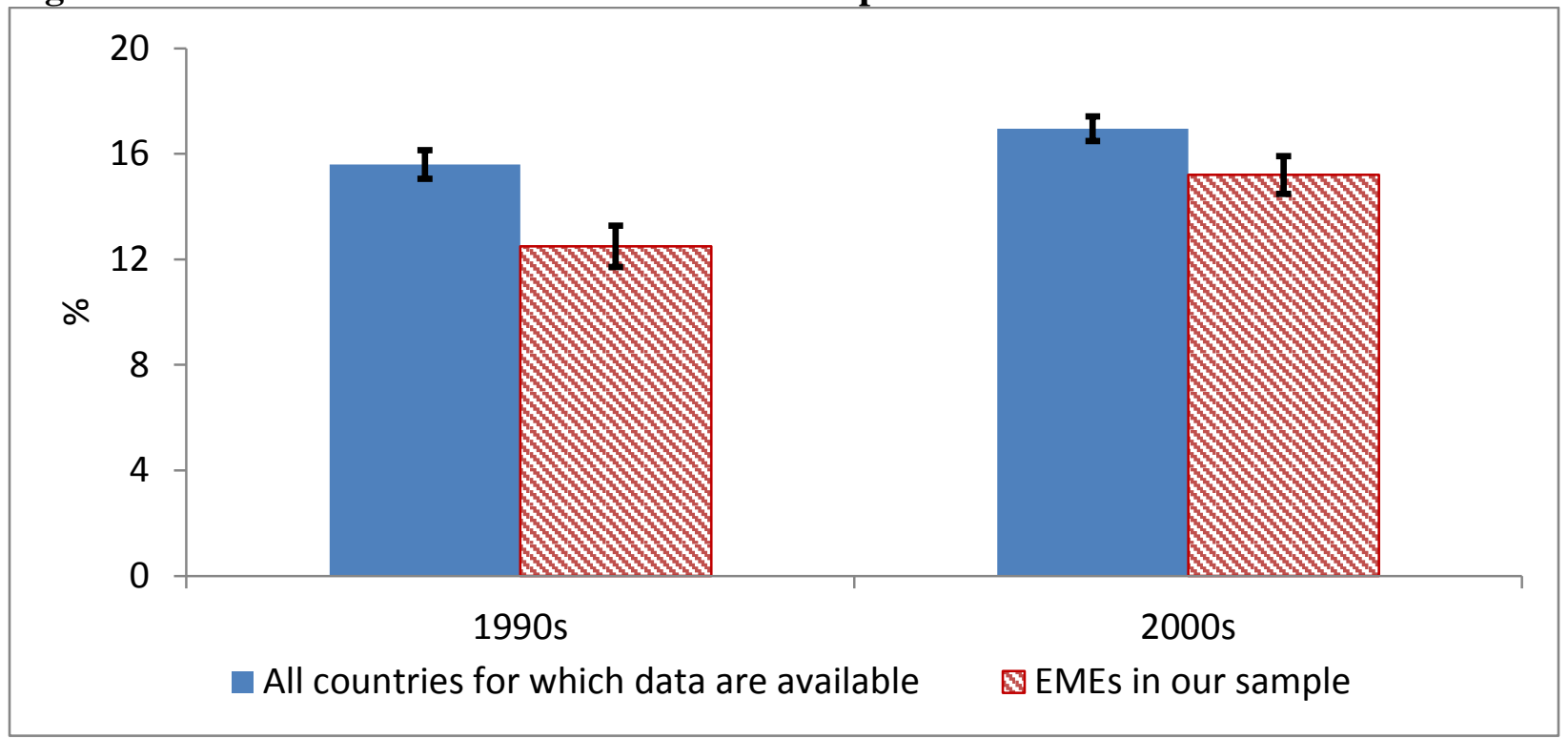

Note: The plotted values are mean for the decade for each group of countries and the $95 \%$ confidence interval around the mean. Source: World Bank WDI

\section{Methodology and Data}

In this section, we describe the methodology used to assess the relative importance of NKI versus fiscal concerns in determining the capital outflows policy. The main hypotheses are that the larger the fiscal reliance on revenues from repression, the fewer the easings of outflows, and the larger the overheating or exchange rate valuation pressures, the greater the incentive to liberalize. The response to macroeconomic volatility or financial stability concerns arising from NKI could be ambiguous - countries may want to liberalize outflows to build a buffer of foreign investments or to close capital accounts to insulate them from external shocks. The dependent variable is the number of net easings of outflows in a quarter by each country. The main regression equation is

$$
\text { Number of Net Easings } s_{i t}=\alpha+\beta X_{i t-1}+v_{i}+u_{t}+e_{i t},
$$

where $X_{i t-1}$ are the set of control variables, $v_{i}$ are the country fixed effects, $u_{t}$ are the time fixed effects and $e_{i t}$ are the errors. All equations were estimated using OLS, with robust standard errors reported. ${ }^{21}$ We tested a number of indicators for each of the hypotheses identified in section II; i.e., fiscal concerns, overheating concerns, concerns about macroeconomic stability,

\footnotetext{
${ }^{21}$ Since the number of net easings can be both positive and negative, models such as tobit and probit are not appropriate for use with our data.
} 
foreign exchange valuation concerns and financial stability concerns. These variables and the expected signs of their coefficients are listed below ${ }^{22}$ :

Fiscal Concerns: The main hypothesis is that the greater the fiscal concerns or revenues from repression, the lower the incentive to liberalize outflows.

1. Measures of fiscal space: More fiscal space allows greater liberalization

(i) Fiscal balance/tax revenues (+)

(ii) Government debt/tax revenues (-)

2. Revenue from external repression (-)

3. Liquidation tax (-): This variable is the negative of the real interest rate on domestic government debt. The expected sign is negative, since higher tax means more potential revenue that could be lost by liberalization and therefore a lower incentive to liberalize. 4. Real deposit rate on bank deposits (+): The expected sign is positive, since the lower rate suggests greater internal repression and therefore a lower incentive to liberalize.

5. Banking sector net lending to government (as a share of total bank assets)*inflation (-): The expected sign is negative, since higher values of this variable imply greater revenues from internal repression.

NKI Concerns: The variables measuring NKI concerns are grouped by hypotheses:

I. Concerns about "overheating”: Greater overheating pressures would create incentive to liberalize, in order to reduce the size of NKI

1. We use two variables that capture the size of the NKI:

(i) NKI/GDP (+)

(ii) NKI surge dummy $(+)$

2. Credit growth $(+)$

3. Credit gap (+): This variable is the ratio of domestic credit/GDP to its 3-year trend

4. Inflation rate $(+)$

5. GDP growth $(+)$

II. Concerns about FX valuation:

1. REER appreciation over the past year $(+)$

2. Change in FX reserves/GDP (+)

3. FX regime (-): This is a dummy variable which takes the value 1 for freely floating exchange rate regimes, and 0 otherwise

4. IT monetary policy dummy (-)

5. Exchange market pressure (EMP) (-): This variable is defined as the sum of exchange rate depreciation and reserve outflows (scaled by reserve money). Higher values of this

\footnotetext{
${ }^{22}$ The data appendix Table A.3 lists the data sources and granularity of each variable; Table A.4 provides their summary statistics.
} 
variable indicate greater depreciation pressure, which would create an incentive to tighten outflow controls.

6. Undervaluation (PPP-based) (-)

III. Concerns about Macro-stability: These variables are defined as 3-year rolling standard deviations of the underlying variables.

1. NKI volatility (+/-)

2. GDP growth volatility (+/-)

3. FX volatility (+/-): The underlying variable is monthly REER change

4. Equity return volatility (+/-): The underlying variable is monthly equity market return

IV. Concerns about Financial Stability:

1. Balance-sheet exposure (-): This variable is defined as (External Debt - Reserves)/GDP. The expected sign is negative, since countries with higher balance-sheet exposure may want to limit current and future outflows (in the event of a crisis).

2. Short-term balance-sheet exposure (-): (Short-Term External Debt - Reserves)/GDP

3. Surge (in gross inflows) $(+)$

4. Sudden stop (in gross inflows) $(+)$

5. Flight (surge in gross outflows) (-)

6. Increase in stock price index over past year $(+)$

7. Inflation crisis (-)

8. Banking crisis (-)

\section{Other controls:}

1. Trade/GDP (+): The expected sign is positive, since the effectiveness of existing controls would decrease with greater trade openness.

2. Chinn-Ito index of capital account openness (-): The expected sign is negative, as moreopen countries are expected to have liberalized less since they had fewer controls left to remove.

3. Quinn index of capital account openness (-)

4. Net tightening of inflows (+/-): Both easing of outflows and tightening of inflows are net capital inflows reducing measures, and therefore may be substitutes. However, countries facing a large NKI surge may be tempted to try both.

All explanatory variables except the dummy variables are normalized by subtracting the intercountry mean and dividing by the standard deviation, so that the regression coefficients can be interpreted as the impact on net easings of a one standard deviation change in the explanatory variables. To control for potential endogeneity, all the explanatory variables are lagged one quarter. We also drop outliers, which are defined as observations that lie more than five standard deviations from the mean of each variable for all explanatory variables. In addition, the extreme 
values of net easings of outflows and the number of net tightening of inflows are also considered outliers (outside the range [-8,9] for net easing of outflows and [-8,8] for net tightening of inflows), and excluded from the reported regression results.

Since each of the concerns has several available proxies, we ran the regressions sequentially. In the first set of regressions, each variable for each hypothesis was first tested individually in bivariate regressions, and then all variables for the given hypothesis were added as a group in multivariate regressions for each hypothesis. From these regressions, all variables that were significant at the $20 \%$ level of significance or less were used in the joint test of the hypothesis. We report only the results of the first stage for the fiscal concerns and the multivariate regressions. The number of zeros in the left-hand-side variable is large, since the dataset is quarterly and outflow policy does not change every quarter for most countries. Using OLS on the dataset would tend to produce estimates of coefficients that are biased toward zero and have inflated standard errors. As a robustness check, we also performed the second-stage regression after dropping all the zeros - results are consistent with those described in the paper, and are available on request.

\section{Results}

The first-stage results for the fiscal variables are shown in Table 2. In the full sample of countries, none of the fiscal variables are significant at conventional levels of significance, suggesting that (in contrast to the 1980s) these variables were not important in the decision to change capital outflow policy. To compare the fiscal and the NKI motivations, we report the second-stage regressions with both sets of indicators in Table 3. Due to concerns about correlation between the explanatory variables, particularly those related through the dimensions of the impossible trinity or the trilemma (size of net capital inflows, capital account openness, exchange rate stability and reserves accumulation), we add each of these variables individually first in columns (1)-(7) and then jointly in columns (8)-(11).

We find that, among the two hypotheses, most of the significant variables are associated with concerns related to NKI, confirming the use of outflow controls in NKI management policy (Table 3). Countries liberalized more in response to overheating and appreciation pressures (as evidenced by the sign and significance of variable stock price inflation and exchange market pressure and REER volatility). They liberalized outflows less in the face of financial stability concerns or macroeconomic volatility. The coefficients of short-term balance-sheet exposure and NKI volatility are negative and significant. In fact, these two variables had the largest coefficients, suggesting that they posed an important constraint to the decision to be more open to capital flows. Further, more-open EMEs liberalized less frequently than less-open EMEs. 
Although the fiscal balance variable has a positive sign and is significant in some regressions, suggesting that countries with better fiscal positions liberalized more, the measures of internal or external repression revenues are not significant. ${ }^{23}$

The results reported in Table 3 suggest not only that fiscal concerns did not post a binding constraint on the liberalization of outflows, but also that any constraints on this liberalization came from the perceived impact of greater openness on macroeconomic volatility and financial stability.

To test the robustness of our results, we divide the countries into groups according to their degree of capital outflow openness at the beginning of the sample period, their exchange rate regime and whether they had a monetary policy with an explicit inflation target. Countries with tighter capital outflow controls at the beginning of the sample period would have greater leeway to use outflow policy changes to manage NKI pressures, but may also be more constrained by fiscal concerns if their reliance on repression revenues is greater. In the closed-economy subsample, we therefore expect to see the fiscal variable play a larger role than in the full sample. Further, as Table 1 showed, non-flexible exchange rate regimes and non-IT countries used net outflow easings more frequently than others. Table 4 shows that these countries were also less open on the capital account, and had worse fiscal balances and higher repression revenues, on average, than their counterparts. Therefore, we would expect to see stronger fiscal policy constraints in the subsamples of non-flexible exchange rate and non-IT monetary policy regimes.

We use Schindler's index of outflow restrictions in the year 2000 to group countries into those that had higher-than-median restrictions to begin with (more-closed economies) and those with lower-than-median restrictions (more-open economies). We use the IMF AREAER classification to group countries that had freely floating and non-freely floating exchange rates, and to group countries that had an explicit IT monetary policy and those that did not.

The results for subgroups of countries that were less open, that had a non-flexible exchange rate regime and that had IT and non-IT monetary policy regimes are shown in Tables 5-8, respectively. ${ }^{24}$ The results of the subgroups are very similar to those for the full sample. The concerns about size and volatility of net capital inflows and the resulting overheating, balancesheet exposures and appreciation pressures are still the most important explanatory variables. Our expectation that fiscal variables would have higher importance in the decision to liberalize outflow controls is confirmed only in the sample of closed economies, and to some extent for non-IT countries. Closed economies were less likely to ease when external repression revenues

\footnotetext{
${ }^{23}$ The R-squares in the regressions are not very high and we do not explain more than $17 \%$ of the variation in the full sample. Several factors could account for this - foremost among them being the high frequency of zeros in the sample. A total of 121 non-zero net easings of outflows in our sample of 456 observations are used in the second to fourth columns of Table 3.

${ }^{24}$ The number of non-zero observations of the dependent variable for country groups with open economies and flexible exchange rate regimes was very low. We therefore do not report these results.
} 
and the inflation tax on bank lending to government were higher. The latter variable is also significant in the sample of non-IT countries. Both IT and non-IT regimes were more likely to ease when fiscal balances were higher. The anomaly is the sign of the liquidation tax variable, which suggests that, in the samples of closed economies and non-IT regimes, countries with higher liquidation tax liberalized more. However, this may simply reflect the fact that liquidation tax was negative for most countries in our sample. In the sample of non-flexible exchange rate regimes, variables related to NKI concerns were the only ones that showed strong associations with liberalization.

\section{Conclusions and Interpretations}

This paper documents a steep decline in revenues from external repression in EMEs during the 2000s compared to the earlier decades. Further, our results indicate that most of the significant associations of outflow liberalizations in the 2000s were with concerns related to net capital inflows. EMEs facing high volatility in net capital inflows and higher balancesheet exposures liberalized less. Countries eased more in response to higher net capital inflows, and when these inflows translated into higher appreciation pressure in the exchange market, higher real exchange rate volatility and greater accumulation of reserves. Unlike in the 1980s, we find that fiscal variables are of very limited importance in explaining the liberalization of capital outflow controls. Only in the sample of relatively closed countries do we see a negative association of greater external repression revenues with easing of outflows.

The remarkable decline in the fiscal reliance on external repression is good news, given that it was accompanied by deeper tax collection from a broader base. However, it begs the question of the future of financial repression. History suggests that one should be cautious in extrapolating from recent trends. The growth acceleration of China and India, and the illusive great moderation prior to the global crisis of 2008-09, probably contributed to the declining reliance on repression revenues. Yet, a reversal of favorable trends frequently changes attitudes toward financial repression (Reinhart et al. 2011). History also suggests that EMEs may rely on financial repression as a contingent tax in the wake of realized bad tail events (as evidenced by the experience of Argentina in the early 2000s). 


\section{References}

Aizenman, Joshua and Pablo E. Guidotti (1994) "Capital Controls, Collection Costs and Domestic Public Debt” Journal of International Money and Finance, 13, 1: 41-54.

Aizenman, Joshua and Yothin Jinjarak (2009) "Globalisation and Developing Countries - a Shrinking Tax Base?” The Journal of Development Studies, 45, 5: 653-671.

Alesina, Alberto, Grilli, Vittorio and Gian Maria Milesi-Ferretti (1994) “The Political Economy of Capital Controls” in Leonardo Leiderman and Assaf Razin, eds., Capital Mobility: The Impact on Consumption, Investment and Growth, Cambridge University Press.

Bird, Richard and Pierre-Pascal Gendron (2011) The VAT in Developing and Transitional Countries, Cambridge University Press.

Broner, Fernando A., Didier, Tatiana, Erce, Aitor and Sergio Schmukler (2011) “Gross Capital Flows: Dynamics and Crises” Banco de Espana Working Paper No. 1039. Available at SSRN: http://dx.doi.org/10.2139/ssrn.1825011.

Chinn, Menzie D. and Hiro Ito (2008). “A New Measure of Financial Openness” Journal of Comparative Policy Analysis, 10, 3: 309-322 (September).

Das, Udaibir, Papaioannou, Michael and Christoph Trebesch (2012), "Sovereign Debt Restructurings 1950 - 2010: Literature Survey, Data, and Stylized Facts” IMF Working Paper 12/203, International Monetary Fund.

Dooley, Michael P. (1996) “A Survey of Academic Literature on Controls over International Capital Transactions” IMF Staff Papers, 43, 4: 639-687.

Edwards, Sebastian (2007) “Capital Controls, Sudden Stops, and Current Account Reversals” in Capital Controls and Capital Flows in Emerging Economies: Policies, Practices and Consequences, University of Chicago Press.

Eichengreen, Barry (2001) “Capital Account Liberalization: What do Cross-Country Studies Tell Us?” World Bank Economic Review, 15, 3: 341-365.

Fratzscher, Marcel (2012) “Capital Controls and Foreign Exchange Policy” European Central Bank Working Paper No. 1415, February.

Giovannini, Alberto and Martha de Melo (1993) "Government Revenue from Financial Repression” American Economic Review, 83, 4: 953-963.

Grilli, Vittorrio and Gian Maria Milesi-Ferretti (1995) "Economic Effects and Structural Determinants of Capital Controls” IMF Staff Papers, 42, 3: 517-551. 
Hutchison, Michael, Pasricha, Gurnain and Nirvikar Singh (2012) "Effectiveness of Capital Controls in India: Evidence from the Offshore NDF Market" IMF Economic Review, 60, 3: 395438.

IMF (2011a) "Recent experiences in managing capital inflows: Cross-cutting themes and possible framework” IMF Policy Paper, February.

IMF (2011b) “International Capital Flows: Reliable or Fickle?” World Economic Outlook, Chapter 4, April 2011.

Kaminsky, Graciela L., Reinhart, Carmen M. and Carlos A. Végh (2005) "When It Rains, It Pours: Procyclical Capital Flows and Macroeconomic Policies" NBER Macroeconomics Annual 2004, Volume 19 (2005), MIT Press.

Klein, Michael W. (2012) “Capital controls: Gates and walls”, Brookings Working Paper, September.

Lardy, Nicolas R. (2008) “Financial Repression in China” Paterson Institute for International Economics Policy Brief, PB08-8, September.

Ostry, Jonathan D., Ghosh, Atish R., Habermeier, Karl, Laeven, Luc, Chamon, Marcos, Qureshi, Mahvash S., and Annamaria Kokenyne (2011) "Managing Capital Inflows: What Tools to Use?" IMF Staff Discussion Note, April.

Pasricha, Gurnain Kaur (2012) "Measures to manage capital flows in emerging market economies" North American Journal of Economics and Finance, special issue on "International Finance in the aftermath of the 2008 Global Crisis” 23, 3: 286-309.

Patnaik, Ila and Ajay Shah (2012), "Did the Indian capital controls work as a tool of macroeconomic policy?” IMF Economic Review, September.

Quinn, Dennis P. (1997) "The Correlates of Change in International Financial Regulation” American Political Science Review, 91, 531-551 (September).

Quinn, Dennis P. and A. Maria Toyoda (2008) "Does Capital Account Liberalization Lead to Economic Growth?” Review of Financial Studies 21(3): 1403-1449.

Reinhart, M. Carmen, Kirkegaard, Jacob F. and M. Belen Sbrancia (2011) "Financial Repression Redux" Finance and Development, 48, 1: 22-26.

Reinhart, M. Carmen and Kenneth S. Rogoff (2011) "From Financial Crash to Debt Crisis" American Economic Review, American Economic Association, 101(5), 1676-1706, August.

Schindler, Martin (2009) “Measuring Financial Integration: A New Data Set” IMF Staff Papers, Palgrave Macmillan, vol. 56(1), pages 222-238, April. 
Warnock, Francis E. (2011) “Doubts about capital controls”, report, Council on Foreign Relations, April. 


\begin{tabular}{|c|c|c|c|c|c|c|c|c|c|}
\hline & $\begin{array}{c}\text { All } \\
\text { Measures }\end{array}$ & $\begin{array}{l}\text { Outflow } \\
\text { Easings }\end{array}$ & $\begin{array}{c}\text { Outflow } \\
\text { Tightenings }\end{array}$ & $\begin{array}{c}\text { Net Outflow } \\
\text { Easings }\end{array}$ & $\begin{array}{c}\text { Inflow } \\
\text { Tightenings }\end{array}$ & $\begin{array}{c}\text { NKI } \\
\text { Reducing } \\
\text { Measures } \\
\end{array}$ & $\begin{array}{c}\text { All } \\
\text { Measures }\end{array}$ & $\begin{array}{c}\text { NKI } \\
\text { Reducing } \\
\text { Measures } \\
\end{array}$ & $\begin{array}{l}\text { Outflow } \\
\text { Easings, } \\
\% \text { of NKI } \\
\text { Reducing } \\
\text { measures }\end{array}$ \\
\hline & (A) & (B) & $(C)$ & $(D)=((B)-(C)$ & $(E)$ & $(F)=(B)+(E)$ & \multirow{2}{*}{\multicolumn{3}{|c|}{ (Measures Per Country-Quarter) }} \\
\hline & \multicolumn{6}{|c|}{ (Total Number of Measures) } & & & \\
\hline \multicolumn{10}{|c|}{ IMF Exchange Rate Classifications } \\
\hline Freely Floating & 124 & 76 & 6 & 70 & 15 & 91 & 0.51 & 0.38 & 84 \\
\hline Non-Freely Floating & 540 & 198 & 22 & 176 & 120 & 318 & 1.16 & 0.68 & 62 \\
\hline \multicolumn{10}{|c|}{ IMF Monetary Policy Framework } \\
\hline Inflation Targeting (IT) & 286 & 130 & 9 & 121 & 79 & 209 & 0.72 & 0.53 & 62 \\
\hline non-IT & 378 & 144 & 19 & 125 & 56 & 200 & 1.22 & 0.65 & 72 \\
\hline Total & 664 & 274 & 28 & 246 & 135 & 409 & 0.94 & 0.58 & 67 \\
\hline
\end{tabular}


Table 2: Role of fiscal concerns in decisions to liberalize capital outflows;

Dependent Variable: Number of Net Easings of Outflows

\begin{tabular}{|c|c|c|c|c|c|c|c|c|c|}
\hline & (1) & (2) & (3) & (4) & (5) & (6) & (7) & (8) & (9) \\
\hline IT Monetary Policy & $\begin{array}{l}-0.12 \\
(0.16)\end{array}$ & $\begin{array}{l}-0.12 \\
(0.17)\end{array}$ & $\begin{array}{l}0.07 \\
(0.14)\end{array}$ & $\begin{array}{l}0.06 \\
(0.15)\end{array}$ & $\begin{array}{l}0.03 \\
(0.14)\end{array}$ & $\begin{array}{l}-0.12 \\
(0.16)\end{array}$ & $\begin{array}{l}-0.11 \\
(0.16)\end{array}$ & $\begin{array}{l}0.09 \\
(0.12)\end{array}$ & $\begin{array}{l}0.07 \\
(0.14)\end{array}$ \\
\hline $\begin{array}{l}\text { Free Floating Exchange } \\
\text { Rate Regime }\end{array}$ & $\begin{array}{l}0.01 \\
(0.13)\end{array}$ & $\begin{array}{l}0.00 \\
(0.13)\end{array}$ & $\begin{array}{l}-0.22 * \\
(0.12)\end{array}$ & $\begin{array}{l}-0.19 \\
(0.12)\end{array}$ & $\begin{array}{l}-0.15 \\
(0.13)\end{array}$ & $\begin{array}{l}-0.08 \\
(0.12)\end{array}$ & $\begin{array}{l}-0.08 \\
(0.12)\end{array}$ & $\begin{array}{l}-0.10 \\
(0.12)\end{array}$ & $\begin{array}{l}-0.07 \\
(0.14)\end{array}$ \\
\hline $\begin{array}{l}\text { Capital Account Openness } \\
\text { (Chinn-Ito) }\end{array}$ & $\begin{array}{l}-0.31 * \\
(0.16)\end{array}$ & $\begin{array}{l}-0.30^{*} \\
(0.15)\end{array}$ & $\begin{array}{l}-0.21 \\
(0.15)\end{array}$ & $\begin{array}{l}-0.23 \\
(0.16)\end{array}$ & $\begin{array}{l}-0.24 \\
(0.17)\end{array}$ & $\begin{array}{l}-0.33^{* *} \\
(0.14)\end{array}$ & $\begin{array}{l}-0.31^{* *} \\
(0.14)\end{array}$ & $\begin{array}{l}-0.18 \\
(0.15)\end{array}$ & $\begin{array}{l}-0.27 \\
(0.18)\end{array}$ \\
\hline $\begin{array}{l}\text { No. of Net Tightenings of } \\
\text { Inflow Controls }\end{array}$ & $\begin{array}{l}0.06 \\
(0.07)\end{array}$ & $\begin{array}{l}0.06 \\
(0.07)\end{array}$ & $\begin{array}{l}0.08 \\
(0.07)\end{array}$ & $\begin{array}{l}0.08 \\
(0.07)\end{array}$ & $\begin{array}{l}0.06 \\
(0.07)\end{array}$ & $\begin{array}{l}0.08 \\
(0.07)\end{array}$ & $\begin{array}{l}0.08 \\
(0.07)\end{array}$ & $\begin{array}{l}0.07 \\
(0.07)\end{array}$ & $\begin{array}{l}0.05 \\
(0.08)\end{array}$ \\
\hline $\begin{array}{l}\text { Fiscal Balance/Tax } \\
\text { Revenues, \% }\end{array}$ & $\begin{array}{l}0.05 \\
(0.06)\end{array}$ & & & & & & & $\begin{array}{l}0.07 \\
(0.10)\end{array}$ & $\begin{array}{l}0.11 \\
(0.10)\end{array}$ \\
\hline Gross Govt. Debt/GDP, \% & & $\begin{array}{l}-0.02 \\
(0.10)\end{array}$ & & & & & & $\begin{array}{l}-0.07 \\
(0.10)\end{array}$ & $\begin{array}{l}0.05 \\
(0.16)\end{array}$ \\
\hline $\begin{array}{l}\text { Repression } \\
\text { Revenues/GDP, \% }\end{array}$ & & & $\begin{array}{l}-0.05 \\
(0.07)\end{array}$ & & & & & $\begin{array}{l}-0.02 \\
(0.07)\end{array}$ & \\
\hline $\begin{array}{l}\text { Repression Revenues } \\
\text { (incl. debt revaluation } \\
\text { costs)/GDP, \% }\end{array}$ & & & & $\begin{array}{l}-0.03 \\
(0.03)\end{array}$ & & & & & \\
\hline Liquidation Tax & & & & & $\begin{array}{l}0.04 \\
(0.06)\end{array}$ & & & $\begin{array}{l}0.09 \\
(0.12)\end{array}$ & $\begin{array}{l}0.04 \\
(0.12)\end{array}$ \\
\hline Real Deposit Rate & & & & & & $\begin{array}{l}-0.02 \\
(0.04)\end{array}$ & & $\begin{array}{l}-0.02 \\
(0.08)\end{array}$ & $\begin{array}{l}0.00 \\
(0.08)\end{array}$ \\
\hline (Bank Lending to Govt/ & & & & & & & 0.04 & -0.02 & 0.04 \\
\hline Bank Assets)*Inflation & & & & & & & $(0.04)$ & $(0.15)$ & $(0.10)$ \\
\hline Observations & 623 & 623 & 470 & 470 & 497 & 667 & 667 & 461 & 488 \\
\hline R-squared & 0.09 & 0.09 & 0.12 & 0.12 & 0.10 & 0.10 & 0.10 & 0.12 & 0.10 \\
\hline Number of Countries & 18 & 18 & 15 & 15 & 16 & 18 & 18 & 15 & 16 \\
\hline
\end{tabular}

Notes: All regressions include time fixed effects; Clustered standard errors in parentheses; ${ }^{* * *} \mathrm{p}<0.01,{ }^{* *} \mathrm{p}<0.05,{ }^{*} \mathrm{p}<0.1$

All explanatory variables are lagged one quarter. All variables, except dummies and number of easings/tightenings have been

normalized and outliers have been removed. 
Table 3: Full Sample. Dependent Variable: Number of Net Easings of Outflow Controls

\begin{tabular}{|c|c|c|c|c|c|c|c|c|c|c|c|}
\hline & (1) & $(2)$ & (3) & (4) & (5) & (6) & (7) & $(8)$ & (9) & (10) & $(11)$ \\
\hline IT Monetary Policy & $\begin{array}{l}0.05 \\
(0.12)\end{array}$ & $\begin{array}{l}-0.11 \\
(0.16)\end{array}$ & $\begin{array}{l}-0.11 \\
(0.16)\end{array}$ & $\begin{array}{l}-0.10 \\
(0.16)\end{array}$ & $\begin{array}{l}-0.06 \\
(0.13)\end{array}$ & $\begin{array}{l}-0.10 \\
(0.16)\end{array}$ & $\begin{array}{l}0.04 \\
(0.13)\end{array}$ & $\begin{array}{l}0.12 \\
(0.12)\end{array}$ & $\begin{array}{l}0.09 \\
(0.12)\end{array}$ & $\begin{array}{l}0.05 \\
(0.12)\end{array}$ & $\begin{array}{l}0.03 \\
(0.13)\end{array}$ \\
\hline Free Floating Exchange & -0.19 & -0.09 & -0.05 & -0.07 & -0.12 & -0.08 & -0.11 & -0.17 & -0.15 & -0.22 & -0.24 \\
\hline Rate Regime & $(0.19)$ & $(0.19)$ & $(0.19)$ & $(0.19)$ & $(0.19)$ & $(0.19)$ & $(0.16)$ & $(0.19)$ & $(0.17)$ & $(0.21)$ & $(0.21)$ \\
\hline $\begin{array}{l}\text { No. of Net Tightenings of } \\
\text { Inflow Controls }\end{array}$ & $\begin{array}{l}0.08 \\
(0.07)\end{array}$ & $\begin{array}{l}0.06 \\
(0.07)\end{array}$ & $\begin{array}{l}0.06 \\
(0.07)\end{array}$ & $\begin{array}{l}0.06 \\
(0.07)\end{array}$ & $\begin{array}{l}0.07 \\
(0.09)\end{array}$ & $\begin{array}{l}0.06 \\
(0.07)\end{array}$ & $\begin{array}{l}0.09 \\
(0.07)\end{array}$ & $\begin{array}{l}0.10 \\
(0.09)\end{array}$ & $\begin{array}{l}0.10 \\
(0.09)\end{array}$ & $\begin{array}{l}0.11 \\
(0.09)\end{array}$ & $\begin{array}{l}0.11 \\
(0.10)\end{array}$ \\
\hline $\begin{array}{l}\text { Capital Account Openness } \\
\text { (Chinn-Ito) }\end{array}$ & $\begin{array}{l}-0.32 * \\
(0.15)\end{array}$ & $\begin{array}{l}-0.39 * * \\
(0.16)\end{array}$ & $\begin{array}{l}-0.36^{* *} \\
(0.16)\end{array}$ & $\begin{array}{l}-0.40^{* *} \\
(0.16)\end{array}$ & $\begin{array}{l}-0.35^{* *} \\
(0.14)\end{array}$ & $\begin{array}{l}-0.41 * * \\
(0.15)\end{array}$ & $\begin{array}{l}-0.25^{*} \\
(0.14)\end{array}$ & $\begin{array}{l}-0.27^{*} \\
(0.14)\end{array}$ & $\begin{array}{l}-0.26^{*} \\
(0.13)\end{array}$ & $\begin{array}{l}-0.32 * \\
(0.15)\end{array}$ & $\begin{array}{l}-0.32 * \\
(0.15)\end{array}$ \\
\hline Fiscal Concerns & & & & & & & & & & & \\
\hline Fiscal Balance/GDP, \% & $\begin{array}{l}0.13^{*} \\
(0.07)\end{array}$ & $\begin{array}{l}0.15^{*} \\
(0.08)\end{array}$ & $\begin{array}{l}0.14^{*} \\
(0.08)\end{array}$ & $\begin{array}{l}0.14^{*} \\
(0.07)\end{array}$ & $\begin{array}{l}0.08 \\
(0.14)\end{array}$ & $\begin{array}{l}0.15^{*} \\
(0.08)\end{array}$ & $\begin{array}{l}0.12 \\
(0.08)\end{array}$ & $\begin{array}{l}0.03 \\
(0.14)\end{array}$ & $\begin{array}{l}0.03 \\
(0.15)\end{array}$ & $\begin{array}{l}0.04 \\
(0.14)\end{array}$ & $\begin{array}{l}0.04 \\
(0.15)\end{array}$ \\
\hline Liquidation Tax & $\begin{array}{l}0.12 \\
(0.11)\end{array}$ & $\begin{array}{l}0.10 \\
(0.14)\end{array}$ & $\begin{array}{l}0.11 \\
(0.11)\end{array}$ & $\begin{array}{l}0.10 \\
(0.11)\end{array}$ & $\begin{array}{l}0.09 \\
(0.12)\end{array}$ & $\begin{array}{l}0.11 \\
(0.11)\end{array}$ & $\begin{array}{l}0.15 \\
(0.10)\end{array}$ & $\begin{array}{l}0.19 \\
(0.15)\end{array}$ & $\begin{array}{l}0.12 \\
(0.10)\end{array}$ & $\begin{array}{l}0.14 \\
(0.10)\end{array}$ & $\begin{array}{l}0.07 \\
(0.20)\end{array}$ \\
\hline Repression Revenues/GDP, \% & $\begin{array}{l}-0.14 \\
(0.16)\end{array}$ & & & & & & & $\begin{array}{l}-0.11 \\
(0.14)\end{array}$ & & & \\
\hline $\begin{array}{l}\text { (Bank Lending to Govt./Bank } \\
\text { Assets)*Inflation }\end{array}$ & & $\begin{array}{l}0.00 \\
(0.13)\end{array}$ & & & & & & $\begin{array}{l}-0.15 \\
(0.16)\end{array}$ & & & \\
\hline NKI Concerns & & & & & & & & & & & \\
\hline $\begin{array}{l}\text { Change in Stock Prices, (\% } \\
\text { уоу) }\end{array}$ & $\begin{array}{l}0.13^{* *} \\
(0.05)\end{array}$ & $\begin{array}{l}0.15^{* * *} \\
(0.03)\end{array}$ & $\begin{array}{l}0.15^{* * *} \\
(0.03)\end{array}$ & $\begin{array}{l}0.15^{* * *} \\
(0.03)\end{array}$ & $\begin{array}{l}0.14^{* * *} \\
(0.04)\end{array}$ & $\begin{array}{l}0.15^{* * *} \\
(0.03)\end{array}$ & $\begin{array}{l}0.15^{* * *} \\
(0.03)\end{array}$ & $\begin{array}{l}0.14 * * * \\
(0.04)\end{array}$ & $\begin{array}{l}0.15^{* * *} \\
(0.04)\end{array}$ & $\begin{array}{l}0.16^{* *} \\
(0.05)\end{array}$ & $\begin{array}{l}0.16^{* *} \\
(0.05)\end{array}$ \\
\hline Gross Inflow Stop & $\begin{array}{l}-0.21 * \\
(0.11)\end{array}$ & $\begin{array}{l}-0.23^{* *} \\
(0.10)\end{array}$ & $\begin{array}{l}-0.19 \\
(0.11)\end{array}$ & $\begin{array}{l}-0.17 \\
(0.11)\end{array}$ & $\begin{array}{l}-0.20 \\
(0.12)\end{array}$ & $\begin{array}{l}-0.24 * * \\
(0.10)\end{array}$ & $\begin{array}{l}-0.27 * * \\
(0.10)\end{array}$ & $\begin{array}{l}-0.21 \\
(0.12)\end{array}$ & $\begin{array}{l}-0.20 \\
(0.12)\end{array}$ & $\begin{array}{l}-0.12 \\
(0.14)\end{array}$ & $\begin{array}{l}-0.12 \\
(0.15)\end{array}$ \\
\hline Flight & $\begin{array}{l}-0.18 \\
(0.12)\end{array}$ & $\begin{array}{l}-0.13 \\
(0.12)\end{array}$ & $\begin{array}{l}-0.11 \\
(0.12)\end{array}$ & $\begin{array}{l}-0.13 \\
(0.13)\end{array}$ & $\begin{array}{l}-0.04 \\
(0.09)\end{array}$ & $\begin{array}{l}-0.14 \\
(0.12)\end{array}$ & $\begin{array}{l}-0.15 \\
(0.12)\end{array}$ & $\begin{array}{l}-0.09 \\
(0.09)\end{array}$ & $\begin{array}{l}-0.07 \\
(0.08)\end{array}$ & $\begin{array}{l}-0.03 \\
(0.11)\end{array}$ & $\begin{array}{l}-0.03 \\
(0.11)\end{array}$ \\
\hline REER Volatility & $\begin{array}{l}0.10^{*} \\
(0.05)\end{array}$ & $\begin{array}{l}0.11^{*} \\
(0.06)\end{array}$ & $\begin{array}{l}0.12 * * \\
(0.05)\end{array}$ & $\begin{array}{l}0.11^{*} \\
(0.06)\end{array}$ & $\begin{array}{l}0.11^{*} \\
(0.05)\end{array}$ & $\begin{array}{l}0.10 \\
(0.06)\end{array}$ & $\begin{array}{l}0.14^{* * *} \\
(0.04)\end{array}$ & $\begin{array}{l}0.13^{*} \\
(0.07)\end{array}$ & $\begin{array}{l}0.11 * * \\
(0.05)\end{array}$ & $\begin{array}{l}0.09 * \\
(0.04)\end{array}$ & $\begin{array}{l}0.09^{*} \\
(0.05)\end{array}$ \\
\hline NKI Volatility & $\begin{array}{l}-0.27 * * \\
(0.11)\end{array}$ & $\begin{array}{l}-0.34^{* *} \\
(0.13)\end{array}$ & $\begin{array}{l}-0.36^{* *} \\
(0.13)\end{array}$ & $\begin{array}{l}-0.32^{* *} \\
(0.13)\end{array}$ & $\begin{array}{l}-0.38^{* *} \\
(0.13)\end{array}$ & $\begin{array}{l}-0.33^{* *} \\
(0.12)\end{array}$ & $\begin{array}{l}-0.32 * * * \\
(0.09)\end{array}$ & $\begin{array}{l}-0.34 * * * \\
(0.10)\end{array}$ & $\begin{array}{l}-0.34 * * * \\
(0.09)\end{array}$ & $\begin{array}{l}-0.39 * * * \\
(0.10)\end{array}$ & $\begin{array}{l}-0.38 * * * \\
(0.10)\end{array}$ \\
\hline NKI/GDP, \% & & & $\begin{array}{l}0.10 \\
(0.08)\end{array}$ & & & & & $\begin{array}{l}-0.01 \\
(0.08)\end{array}$ & $\begin{array}{l}0.00 \\
(0.08)\end{array}$ & $\begin{array}{l}-0.03 \\
(0.08)\end{array}$ & $\begin{array}{l}-0.03 \\
(0.08)\end{array}$ \\
\hline EMP & & & & $\begin{array}{l}-0.11^{* *} \\
(0.04)\end{array}$ & & & & $\begin{array}{l}-0.08^{* *} \\
(0.03)\end{array}$ & $\begin{array}{l}-0.08^{* *} \\
(0.03)\end{array}$ & $\begin{array}{l}-0.08 * * \\
(0.03)\end{array}$ & $\begin{array}{l}-0.08^{* *} \\
(0.03)\end{array}$ \\
\hline$\Delta$ (Reserves/GDP, \%) & & & & & $\begin{array}{l}0.05 \\
(0.08)\end{array}$ & & & $\begin{array}{l}0.03 \\
(0.08)\end{array}$ & $\begin{array}{l}0.02 \\
(0.08)\end{array}$ & $\begin{array}{l}0.06 \\
(0.08)\end{array}$ & $\begin{array}{l}0.06 \\
(0.08)\end{array}$ \\
\hline REER Appreciation & & & & & & $\begin{array}{l}0.04 \\
(0.04)\end{array}$ & & $\begin{array}{l}0.03 \\
(0.04)\end{array}$ & $\begin{array}{l}0.03 \\
(0.04)\end{array}$ & $\begin{array}{l}0.06 \\
(0.04)\end{array}$ & $\begin{array}{l}0.06 \\
(0.04)\end{array}$ \\
\hline $\begin{array}{l}\text { (Short Term External Debt- } \\
\text { Reserves)/GDP, \% }\end{array}$ & & & & & & & $\begin{array}{l}-0.39 * * * \\
(0.08)\end{array}$ & $\begin{array}{l}-0.29 * * * \\
(0.07)\end{array}$ & $\begin{array}{l}-0.29 * * * \\
(0.06)\end{array}$ & $\begin{array}{l}-0.25^{* * * *} \\
(0.07)\end{array}$ & $\begin{array}{l}-0.24^{* * *} \\
(0.06)\end{array}$ \\
\hline Real GDP Growth, (\% yoy) & & & & & & & & & & $\begin{array}{l}0.14 \\
(0.09)\end{array}$ & $\begin{array}{l}0.14 \\
(0.09)\end{array}$ \\
\hline Trade/GDP, \% & & & & & & & & & & $\begin{array}{l}0.18 \\
(0.32)\end{array}$ & $\begin{array}{l}0.15 \\
(0.32)\end{array}$ \\
\hline Inflation, \% & & & & & & & & & & & $\begin{array}{l}0.08 \\
(0.19)\end{array}$ \\
\hline Observations & 429 & 456 & 456 & 456 & 440 & 456 & 432 & 413 & 416 & 408 & 408 \\
\hline R-squared & 0.14 & 0.13 & 0.13 & 0.13 & 0.13 & 0.13 & 0.15 & 0.16 & 0.16 & 0.17 & 0.17 \\
\hline Number of Countries & 14 & 15 & 15 & 15 & 15 & 15 & 14 & 14 & 14 & 13 & 13 \\
\hline
\end{tabular}

Notes: All regressions include time fixed effects; Clustered standard errors in parentheses; ${ }^{* * *} \mathrm{p}<0.01,{ }^{* *} \mathrm{p}<0.05,{ }^{*} \mathrm{p}<0.1$. All explanatory variables are lagged one quarter. All variables, except dummies and number of easings/tightenings have been normalized and outliers have been removed. 


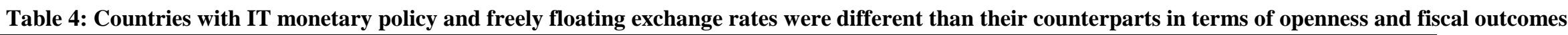

Capital Account Openness Trade/GDP Fiscal Balance/Tax Repression

Quinn Index Chinn-Ito Index

(\%) Revenues (\%)

Revenues/GDP (\%)

\begin{tabular}{|c|c|c|c|c|c|}
\hline & \multicolumn{5}{|c|}{ (Mean over sample period) } \\
\hline Non-IT Countries & 50.6 & -0.12 & 74.01 & -19.52 & 0.04 \\
\hline IT Countries & 68.89 & 0.31 & 64.13 & -8.93 & -0.32 \\
\hline \multicolumn{6}{|l|}{ Non-Freely Floating Exchange Rate } \\
\hline Regimes & 55.4 & 0.11 & 71.8 & -15.89 & 0.01 \\
\hline Freely Floating Exchange Rate Regimes & 71.38 & 0.14 & 62.03 & -8.82 & -0.51 \\
\hline
\end{tabular}


Table 5: Less-Open Economies (Countries with higher-than-median capital outflow controls in 2000); Dependent Variable: Number of Net Easings of Outflows

\begin{tabular}{|c|c|c|c|c|c|c|c|c|c|c|c|}
\hline & (1) & $(2)$ & (3) & (4) & (5) & (6) & $(7)$ & $(8)$ & (9) & $(10)$ & $(11)$ \\
\hline IT Monetary Policy & $\begin{array}{l}-0.17 \\
(0.24)\end{array}$ & $\begin{array}{l}-0.33 \\
(0.26)\end{array}$ & $\begin{array}{l}-0.26 \\
(0.29)\end{array}$ & $\begin{array}{l}-0.23 \\
(0.29)\end{array}$ & $\begin{array}{l}-0.13 \\
(0.27)\end{array}$ & $\begin{array}{l}-0.32 \\
(0.26)\end{array}$ & $\begin{array}{l}-0.08 \\
(0.18)\end{array}$ & $\begin{array}{l}0.13 \\
(0.21)\end{array}$ & $\begin{array}{l}0.13 \\
(0.30)\end{array}$ & $\begin{array}{l}0.35 \\
(0.33)\end{array}$ & $\begin{array}{l}0.35 \\
(0.31)\end{array}$ \\
\hline $\begin{array}{l}\text { Free Floating Exchange } \\
\text { Rate Regime }\end{array}$ & $\begin{array}{l}-0.68 \\
(0.42)\end{array}$ & $\begin{array}{l}-0.20 \\
(0.57)\end{array}$ & $\begin{array}{l}-0.17 \\
(0.50)\end{array}$ & $\begin{array}{l}-0.20 \\
(0.52)\end{array}$ & $\begin{array}{l}-0.21 \\
(0.50)\end{array}$ & $\begin{array}{l}-0.27 \\
(0.54)\end{array}$ & $\begin{array}{l}-0.19 \\
(0.59)\end{array}$ & $\begin{array}{l}-0.21 \\
(0.45)\end{array}$ & $\begin{array}{l}-0.08 \\
(0.53)\end{array}$ & $\begin{array}{l}-0.08 \\
(0.52)\end{array}$ & -0.13 \\
\hline No. of Net Tightenings of & 0.14 & 0.11 & 0.11 & 0.12 & 0.13 & 0.11 & 0.16 & 0.18 & 0.19 & 0.22 & 0.23 \\
\hline Inflow Controls & $(0.12)$ & $(0.13)$ & $(0.13)$ & $(0.13)$ & $(0.17)$ & $(0.13)$ & $(0.13)$ & $(0.16)$ & $(0.17)$ & $(0.19)$ & $(0.20)$ \\
\hline $\begin{array}{l}\text { Capital Account Openness } \\
\text { (Chinn-Ito) }\end{array}$ & $\begin{array}{l}-0.47^{*} \\
(0.23)\end{array}$ & $\begin{array}{l}-0.49 * * \\
(0.19)\end{array}$ & $\begin{array}{l}-0.44^{*} \\
(0.20)\end{array}$ & $\begin{array}{l}-0.49^{* *} \\
(0.20)\end{array}$ & $\begin{array}{l}-0.48^{*} \\
(0.24)\end{array}$ & $\begin{array}{l}-0.53^{* *} \\
(0.17)\end{array}$ & $\begin{array}{l}-0.43^{*} \\
(0.21)\end{array}$ & $\begin{array}{l}-0.70^{* *} \\
(0.22)\end{array}$ & $\begin{array}{l}-0.51^{* *} \\
(0.19)\end{array}$ & $\begin{array}{l}-0.71^{* *} \\
(0.21)\end{array}$ & $\begin{array}{l}-0.72 * * \\
(0.24)\end{array}$ \\
\hline Fiscal Concerns & & & & & & & & & & & \\
\hline 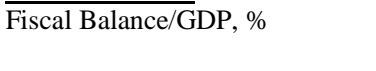 & $\begin{array}{l}0.13 \\
(0.10)\end{array}$ & $\begin{array}{l}0.16 \\
(0.11)\end{array}$ & $\begin{array}{l}0.16 \\
(0.11)\end{array}$ & $\begin{array}{l}0.15 \\
(0.11)\end{array}$ & $\begin{array}{l}0.09 \\
(0.19)\end{array}$ & $\begin{array}{l}0.16 \\
(0.11)\end{array}$ & $\begin{array}{l}0.11 \\
(0.10)\end{array}$ & $\begin{array}{l}0.03 \\
(0.19)\end{array}$ & $\begin{array}{l}0.02 \\
(0.19)\end{array}$ & $\begin{array}{l}0.06 \\
(0.18)\end{array}$ & $\begin{array}{l}0.06 \\
(0.18)\end{array}$ \\
\hline Liquidation Tax & $\begin{array}{l}0.32 \\
(0.18)\end{array}$ & $\begin{array}{l}0.49 * \\
(0.22)\end{array}$ & $\begin{array}{l}0.36^{*} \\
(0.19)\end{array}$ & $\begin{array}{l}0.38^{*} \\
(0.19)\end{array}$ & $\begin{array}{l}0.40 \\
(0.25)\end{array}$ & $\begin{array}{l}0.40^{*} \\
(0.19)\end{array}$ & $\begin{array}{l}0.29 \\
(0.18)\end{array}$ & $\begin{array}{l}0.84 * * * \\
(0.20)\end{array}$ & $\begin{array}{l}0.30 \\
(0.22)\end{array}$ & $\begin{array}{l}0.43^{* *} \\
(0.16)\end{array}$ & $\begin{array}{l}0.31 \\
(0.31)\end{array}$ \\
\hline Repression Revenues/GDP, \% & $\begin{array}{l}-0.38^{*} \\
(0.19)\end{array}$ & & & & & & & $\begin{array}{l}-0.47^{* *} \\
(0.13)\end{array}$ & & & \\
\hline Change in Stock Prices, (\% yoy) & $\begin{array}{l}0.07 \\
(0.09)\end{array}$ & $\begin{array}{l}0.13^{* *} \\
(0.05)\end{array}$ & $\begin{array}{l}0.13^{*} \\
(0.06)\end{array}$ & $\begin{array}{l}0.11^{*} \\
(0.06)\end{array}$ & $\begin{array}{l}0.11^{*} \\
(0.05)\end{array}$ & $\begin{array}{l}0.10 \\
(0.06)\end{array}$ & $\begin{array}{l}0.16^{*} \\
(0.08)\end{array}$ & $\begin{array}{l}0.07 \\
(0.11)\end{array}$ & $\begin{array}{l}0.12 \\
(0.11)\end{array}$ & $\begin{array}{l}0.12 \\
(0.12)\end{array}$ & $\begin{array}{l}0.12 \\
(0.12)\end{array}$ \\
\hline Gross Inflow Stop & $\begin{array}{l}-0.53^{* *} \\
(0.17)\end{array}$ & $\begin{array}{l}-0.58^{*} \\
(0.29)\end{array}$ & $\begin{array}{l}-0.54^{*} \\
(0.28)\end{array}$ & $\begin{array}{l}-0.50^{*} \\
(0.27)\end{array}$ & $\begin{array}{l}-0.53 \\
(0.33)\end{array}$ & $\begin{array}{l}-0.59^{*} \\
(0.29)\end{array}$ & $\begin{array}{l}-0.47^{* *} \\
(0.18)\end{array}$ & $\begin{array}{l}-0.48 \\
(0.34)\end{array}$ & $\begin{array}{l}-0.40 \\
(0.29)\end{array}$ & $\begin{array}{l}-0.36 \\
(0.46)\end{array}$ & $\begin{array}{l}-0.37 \\
(0.48)\end{array}$ \\
\hline Flight & $\begin{array}{l}-0.11 \\
(0.20)\end{array}$ & $\begin{array}{l}-0.04 \\
(0.23)\end{array}$ & $\begin{array}{l}-0.05 \\
(0.23)\end{array}$ & $\begin{array}{l}-0.07 \\
(0.24)\end{array}$ & $\begin{array}{l}0.08 \\
(0.20)\end{array}$ & $\begin{array}{l}-0.05 \\
(0.24)\end{array}$ & $\begin{array}{l}-0.21 \\
(0.26)\end{array}$ & $\begin{array}{l}0.11 \\
(0.23)\end{array}$ & $\begin{array}{l}-0.01 \\
(0.21)\end{array}$ & $\begin{array}{l}0.04 \\
(0.25)\end{array}$ & $\begin{array}{l}0.04 \\
(0.25)\end{array}$ \\
\hline REER Volatility & $\begin{array}{l}0.01 \\
(0.07)\end{array}$ & $\begin{array}{l}0.18 \\
(0.12)\end{array}$ & $\begin{array}{l}0.17 \\
(0.12)\end{array}$ & $\begin{array}{l}0.15 \\
(0.12)\end{array}$ & $\begin{array}{l}0.18 \\
(0.17)\end{array}$ & $\begin{array}{l}0.09 \\
(0.16)\end{array}$ & $\begin{array}{l}0.18 \\
(0.13)\end{array}$ & $\begin{array}{l}-0.01 \\
(0.17)\end{array}$ & $\begin{array}{l}0.05 \\
(0.22)\end{array}$ & $\begin{array}{l}0.16 \\
(0.25)\end{array}$ & $\begin{array}{l}0.16 \\
(0.26)\end{array}$ \\
\hline NKI Volatility & $\begin{array}{l}-0.29 \\
(0.17)\end{array}$ & $\begin{array}{l}-0.49 * * \\
(0.18)\end{array}$ & $\begin{array}{l}-0.50 * * \\
(0.16)\end{array}$ & $\begin{array}{l}-0.45^{* *} \\
(0.18)\end{array}$ & $\begin{array}{l}-0.47^{* *} \\
(0.18)\end{array}$ & $\begin{array}{l}-0.43^{* *} \\
(0.17)\end{array}$ & $\begin{array}{l}-0.41^{*} \\
(0.20)\end{array}$ & $\begin{array}{l}-0.37^{*} \\
(0.19)\end{array}$ & $\begin{array}{l}-0.43^{*} \\
(0.19)\end{array}$ & $\begin{array}{l}-0.56^{* *} \\
(0.16)\end{array}$ & $\begin{array}{l}-0.55^{* *} \\
(0.15)\end{array}$ \\
\hline NKI/GDP, \% & & & $\begin{array}{l}0.09 \\
(0.12)\end{array}$ & & & & & $\begin{array}{l}-0.05 \\
(0.14)\end{array}$ & $\begin{array}{l}0.02 \\
(0.11)\end{array}$ & $\begin{array}{l}-0.07 \\
(0.11)\end{array}$ & $\begin{array}{l}-0.07 \\
(0.11)\end{array}$ \\
\hline EMP & & & & $\begin{array}{l}-0.11^{* *} \\
(0.03)\end{array}$ & & & & $\begin{array}{l}-0.07^{*} \\
(0.04)\end{array}$ & $\begin{array}{l}-0.05 \\
(0.04)\end{array}$ & $\begin{array}{l}-0.06 \\
(0.03)\end{array}$ & $\begin{array}{l}-0.06 \\
(0.04)\end{array}$ \\
\hline$\Delta$ (Reserves/GDP, \%) & & & & & $\begin{array}{l}0.06 \\
(0.10)\end{array}$ & & & $\begin{array}{l}0.10 \\
(0.10)\end{array}$ & $\begin{array}{l}0.04 \\
(0.12)\end{array}$ & $\begin{array}{l}0.13 \\
(0.12)\end{array}$ & $\begin{array}{l}0.13 \\
(0.12)\end{array}$ \\
\hline REER Appreciation & & & & & & $\begin{array}{l}0.08 \\
(0.07)\end{array}$ & & $\begin{array}{l}0.09 \\
(0.07)\end{array}$ & $\begin{array}{l}0.12 * \\
(0.05)\end{array}$ & $\begin{array}{l}0.17^{* * *} \\
(0.03)\end{array}$ & $\begin{array}{l}0.17 * * * \\
(0.03)\end{array}$ \\
\hline $\begin{array}{l}\text { (Short Term External Debt- } \\
\text { Reserves)/GDP, \% }\end{array}$ & & & & & & & $-0.57^{*}$ & & $\begin{array}{l}-0.47 \\
(029)\end{array}$ & -0.24 & $\begin{array}{l}-0.25 \\
(0.18)\end{array}$ \\
\hline Real GDP Growth, (\% yoy) & & & & & & & & & & $\begin{array}{l}0.30 * \\
(0.13)\end{array}$ & $\begin{array}{l}0.31^{*} \\
(0.14)\end{array}$ \\
\hline Trade/GDP, \% & & & & & & & & & & $\begin{array}{l}0.49 \\
(0.40)\end{array}$ & $\begin{array}{l}0.47 \\
(0.35)\end{array}$ \\
\hline Inflation, \% & & & & & & & & & & & $\begin{array}{l}0.12 \\
(0.36)\end{array}$ \\
\hline Observations & 231 & 258 & 258 & 258 & 242 & 258 & 234 & 215 & 218 & 210 & 210 \\
\hline R-squared & 0.23 & 0.19 & 0.19 & 0.19 & 0.19 & 0.19 & 0.22 & 0.25 & 0.23 & 0.27 & 0.27 \\
\hline Number of Countries & 8 & 9 & 9 & 9 & 9 & 9 & 8 & 8 & 8 & 7 & 7 \\
\hline
\end{tabular}

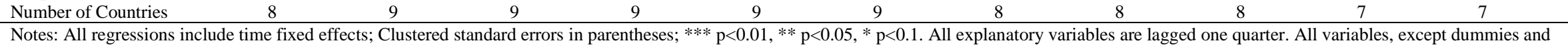
number of easings/tightenings, have been normalized and outliers have been removed. 
Table 6: Non-Freely Floating Exchange Rate Regimes; Dependent Variable: Number of Net Easings of Outflows

\begin{tabular}{|c|c|c|c|c|c|c|c|c|c|c|c|c|}
\hline 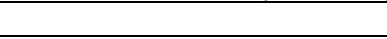 & (1) & $(2)$ & (3) & $(4)$ & $(5)$ & $(6)$ & $(7)$ & $(8)$ & $(9)$ & $(10)$ & $(11)$ & $(12)$ \\
\hline IT Monetary Policy & $\begin{array}{l}0.04 \\
(0.17)\end{array}$ & $\begin{array}{l}-0.13 \\
(0.23)\end{array}$ & $\begin{array}{l}-0.12 \\
(0.24)\end{array}$ & $\begin{array}{l}-0.16 \\
(0.18)\end{array}$ & $\begin{array}{l}-0.14 \\
(0.24)\end{array}$ & $\begin{array}{l}-0.05 \\
(0.19)\end{array}$ & $\begin{array}{l}-0.12 \\
(0.23)\end{array}$ & $\begin{array}{l}0.17 \\
(0.36)\end{array}$ & $\begin{array}{l}0.30 \\
(0.22)\end{array}$ & $\begin{array}{l}0.19 \\
(0.30)\end{array}$ & $\begin{array}{l}0.04 \\
(0.27)\end{array}$ & $\begin{array}{l}0.07 \\
(0.27)\end{array}$ \\
\hline $\begin{array}{l}\text { No. of Net Tightenings of } \\
\text { Inflow Controls }\end{array}$ & $\begin{array}{l}0.08 \\
(0.06)\end{array}$ & $\begin{array}{l}0.09 \\
(0.07)\end{array}$ & $\begin{array}{l}0.09 \\
(0.07)\end{array}$ & $\begin{array}{l}0.09 \\
(0.07)\end{array}$ & $\begin{array}{l}0.09 \\
(0.07)\end{array}$ & $\begin{array}{l}0.11 \\
(0.08)\end{array}$ & $\begin{array}{l}0.09 \\
(0.07)\end{array}$ & $\begin{array}{l}0.11 \\
(0.07)\end{array}$ & $\begin{array}{l}0.12 \\
(0.08)\end{array}$ & $\begin{array}{l}0.12 \\
(0.09)\end{array}$ & $\begin{array}{l}0.12 \\
(0.09)\end{array}$ & $\begin{array}{l}0.12 \\
(0.10)\end{array}$ \\
\hline $\begin{array}{l}\text { Capital Account Openness } \\
\text { (Chinn-Ito) }\end{array}$ & $\begin{array}{l}-0.28 \\
(0.32)\end{array}$ & $\begin{array}{l}-0.34 \\
(0.34)\end{array}$ & $\begin{array}{l}-0.34 \\
(0.33)\end{array}$ & $\begin{array}{l}-0.34 \\
(0.35)\end{array}$ & $\begin{array}{l}-0.38 \\
(0.32)\end{array}$ & $\begin{array}{l}-0.24 \\
(0.28)\end{array}$ & $\begin{array}{l}-0.34 \\
(0.32)\end{array}$ & $\begin{array}{l}-0.36 \\
(0.34)\end{array}$ & $\begin{array}{l}-0.25 \\
(0.36)\end{array}$ & $\begin{array}{l}-0.27 \\
(0.30)\end{array}$ & $\begin{array}{l}-0.18 \\
(0.29)\end{array}$ & $\begin{array}{l}-0.19 \\
(0.32)\end{array}$ \\
\hline \multicolumn{13}{|l|}{ Fiscal Concerns } \\
\hline Fiscal Balance/GDP, \% & $\begin{array}{l}0.01 \\
(0.12)\end{array}$ & $\begin{array}{l}0.03 \\
(0.13)\end{array}$ & $\begin{array}{l}0.03 \\
(0.13)\end{array}$ & $\begin{array}{l}0.01 \\
(0.12)\end{array}$ & $\begin{array}{l}0.02 \\
(0.12)\end{array}$ & $\begin{array}{l}-0.08 \\
(0.22)\end{array}$ & $\begin{array}{l}0.03 \\
(0.13)\end{array}$ & $\begin{array}{l}0.03 \\
(0.13)\end{array}$ & $\begin{array}{l}-0.14 \\
(0.20)\end{array}$ & $\begin{array}{l}-0.13 \\
(0.20)\end{array}$ & $\begin{array}{l}-0.13 \\
(0.20)\end{array}$ & $\begin{array}{l}-0.13 \\
(0.20)\end{array}$ \\
\hline Liquidation Tax & $\begin{array}{l}0.23 \\
(0.15)\end{array}$ & $\begin{array}{l}0.25 \\
(0.22)\end{array}$ & $\begin{array}{l}0.23 \\
(0.16)\end{array}$ & $\begin{array}{l}0.23 \\
(0.15)\end{array}$ & $\begin{array}{l}0.23 \\
(0.16)\end{array}$ & $\begin{array}{l}0.21 \\
(0.15)\end{array}$ & $\begin{array}{l}0.23 \\
(0.16)\end{array}$ & $\begin{array}{l}0.22 \\
(0.16)\end{array}$ & $\begin{array}{l}0.23 \\
(0.25)\end{array}$ & $\begin{array}{l}0.18 \\
(0.15)\end{array}$ & $\begin{array}{l}0.22 \\
(0.13)\end{array}$ & $\begin{array}{l}0.32 \\
(0.39)\end{array}$ \\
\hline Repression Revenues/GDP, \% & $\begin{array}{l}-0.32 \\
(0.26)\end{array}$ & & & & & & & & $\begin{array}{l}-0.25 \\
(0.23)\end{array}$ & & & \\
\hline $\begin{array}{l}\text { (Bank Lending to Govt./Bank } \\
\text { Assets)*Inflation }\end{array}$ & & $\begin{array}{l}-0.03 \\
(0.16)\end{array}$ & & & & & & & $\begin{array}{l}-0.11 \\
(0.28)\end{array}$ & & & \\
\hline \multicolumn{13}{|l|}{ NKI Concerns } \\
\hline Change in Stock Prices, (\% yoy) & $\begin{array}{l}0.11 \\
(0.07)\end{array}$ & $\begin{array}{l}0.14^{*} \\
(0.07)\end{array}$ & $\begin{array}{l}0.13 * * \\
(0.06)\end{array}$ & $\begin{array}{l}0.14^{* *} \\
(0.06)\end{array}$ & $\begin{array}{l}0.14^{* *} \\
(0.06)\end{array}$ & $\begin{array}{l}0.14^{*} \\
(0.06)\end{array}$ & $\begin{array}{l}0.13^{* *} \\
(0.06)\end{array}$ & $\begin{array}{l}0.17 * * \\
(0.07)\end{array}$ & $\begin{array}{l}0.16^{*} \\
(0.08)\end{array}$ & $\begin{array}{l}0.17 * * \\
(0.07)\end{array}$ & $\begin{array}{l}0.17 \\
(0.10)\end{array}$ & $\begin{array}{l}0.18 \\
(0.10)\end{array}$ \\
\hline Gross Inflow Stop & $\begin{array}{l}-0.23^{* *} \\
(0.10)\end{array}$ & $\begin{array}{l}-0.25^{*} \\
(0.12)\end{array}$ & $\begin{array}{l}-0.25^{*} \\
(0.11)\end{array}$ & $\begin{array}{l}-0.17 \\
(0.10)\end{array}$ & $\begin{array}{l}-0.18 \\
(0.11)\end{array}$ & $\begin{array}{l}-0.16 \\
(0.12)\end{array}$ & $\begin{array}{l}-0.25^{*} \\
(0.12)\end{array}$ & $\begin{array}{l}-0.38^{* *} \\
(0.17)\end{array}$ & $\begin{array}{l}-0.26^{*} \\
(0.13)\end{array}$ & $\begin{array}{l}-0.24 \\
(0.14)\end{array}$ & $\begin{array}{l}-0.07 \\
(0.19)\end{array}$ & $\begin{array}{l}-0.07 \\
(0.19)\end{array}$ \\
\hline Flight & $\begin{array}{l}-0.14 \\
(0.14)\end{array}$ & $\begin{array}{l}-0.10 \\
(0.19)\end{array}$ & $\begin{array}{l}-0.10 \\
(0.19)\end{array}$ & $\begin{array}{l}-0.04 \\
(0.20)\end{array}$ & $\begin{array}{l}-0.07 \\
(0.19)\end{array}$ & $\begin{array}{l}0.14 \\
(0.19)\end{array}$ & $\begin{array}{l}-0.10 \\
(0.19)\end{array}$ & $\begin{array}{l}-0.14 \\
(0.17)\end{array}$ & $\begin{array}{l}-0.04 \\
(0.11)\end{array}$ & $\begin{array}{l}0.06 \\
(0.17)\end{array}$ & $\begin{array}{l}0.07 \\
(0.12)\end{array}$ & $\begin{array}{l}0.07 \\
(0.12)\end{array}$ \\
\hline REER Volatility & $\begin{array}{l}0.25^{*} \\
(0.13)\end{array}$ & $\begin{array}{l}0.18 \\
(0.11)\end{array}$ & $\begin{array}{l}0.18 \\
(0.11)\end{array}$ & $\begin{array}{l}0.22 * \\
(0.10)\end{array}$ & $\begin{array}{l}0.18 \\
(0.11)\end{array}$ & $\begin{array}{l}0.17^{*} \\
(0.09)\end{array}$ & $\begin{array}{l}0.18 \\
(0.11)\end{array}$ & $\begin{array}{l}0.19 \\
(0.11)\end{array}$ & $\begin{array}{l}0.28^{*} \\
(0.15)\end{array}$ & $\begin{array}{l}0.21^{*} \\
(0.11)\end{array}$ & $\begin{array}{l}0.12 \\
(0.11)\end{array}$ & $\begin{array}{l}0.12 \\
(0.10)\end{array}$ \\
\hline NKI Volatility & $\begin{array}{l}-0.56^{* *} \\
(0.24)\end{array}$ & $\begin{array}{l}-0.43^{*} \\
(0.22)\end{array}$ & $\begin{array}{l}-0.42 * \\
(0.22)\end{array}$ & $\begin{array}{l}-0.45^{*} \\
(0.23)\end{array}$ & $\begin{array}{l}-0.42^{*} \\
(0.21)\end{array}$ & $\begin{array}{l}-0.43^{*} \\
(0.22)\end{array}$ & $\begin{array}{l}-0.42 * \\
(0.22)\end{array}$ & $\begin{array}{l}-0.30 \\
(0.25)\end{array}$ & $\begin{array}{l}-0.50^{*} \\
(0.25)\end{array}$ & $\begin{array}{l}-0.40 \\
(0.23)\end{array}$ & $\begin{array}{l}-0.50^{*} \\
(0.25)\end{array}$ & $\begin{array}{l}-0.50^{*} \\
(0.25)\end{array}$ \\
\hline NKI/GDP, \% & & & & $\begin{array}{l}0.20 * * \\
(0.09)\end{array}$ & & & & & $\begin{array}{l}0.18 \\
(0.18)\end{array}$ & $\begin{array}{l}0.19 \\
(0.17)\end{array}$ & $\begin{array}{l}0.09 \\
(0.16)\end{array}$ & $\begin{array}{l}0.08 \\
(0.16)\end{array}$ \\
\hline EMP & & & & & $\begin{array}{l}-0.09 \\
(0.05)\end{array}$ & & & & $\begin{array}{l}-0.06 \\
(0.05)\end{array}$ & $\begin{array}{l}-0.05 \\
(0.05)\end{array}$ & $\begin{array}{l}-0.06 \\
(0.04)\end{array}$ & $\begin{array}{l}-0.06 \\
(0.04)\end{array}$ \\
\hline$\Delta$ (Reserves/GDP, \%) & & & & & & $\begin{array}{l}0.11 \\
(0.10)\end{array}$ & & & $\begin{array}{l}-0.05 \\
(0.14)\end{array}$ & $\begin{array}{l}-0.03 \\
(0.13)\end{array}$ & $\begin{array}{l}0.01 \\
(0.13)\end{array}$ & $\begin{array}{l}0.01 \\
(0.13)\end{array}$ \\
\hline REER Appreciation & & & & & & & $\begin{array}{l}0.00 \\
(0.07)\end{array}$ & & $\begin{array}{l}-0.03 \\
(0.07)\end{array}$ & $\begin{array}{l}-0.04 \\
(0.08)\end{array}$ & $\begin{array}{l}0.00 \\
(0.08)\end{array}$ & $\begin{array}{l}0.01 \\
(0.08)\end{array}$ \\
\hline $\begin{array}{l}\text { (Short Term External Debt- } \\
\text { Reserves)/GDP, \% }\end{array}$ & & & & & & & & $\begin{array}{l}-0.52 * * \\
(0.23)\end{array}$ & $\begin{array}{l}-0.44^{*} \\
(0.20)\end{array}$ & $\begin{array}{l}-0.41^{*} \\
(0.20)\end{array}$ & $\begin{array}{l}-0.21 \\
(0.24)\end{array}$ & $\begin{array}{l}-0.22 \\
(0.23)\end{array}$ \\
\hline Real GDP Growth, (\% yoy) & & & & & & & & & & & $\begin{array}{l}0.18 \\
(0.13)\end{array}$ & $\begin{array}{l}0.18 \\
(0.13)\end{array}$ \\
\hline Trade/GDP, \% & & & & & & & & & & & $\begin{array}{l}0.60 \\
(0.54)\end{array}$ & $\begin{array}{l}0.65 \\
(0.61)\end{array}$ \\
\hline Inflation, \% & & & & & & & & & & & & $\begin{array}{l}-0.10 \\
(0.33)\end{array}$ \\
\hline Observations & 251 & 254 & 254 & 254 & 254 & 238 & 254 & 254 & 235 & 238 & 230 & 230 \\
\hline R-squared & 0.21 & 0.19 & 0.19 & 0.20 & 0.19 & 0.19 & 0.19 & 0.20 & 0.22 & 0.21 & 0.24 & 0.24 \\
\hline Number of Countries & 13 & 13 & 13 & 13 & 13 & 13 & 13 & 13 & 13 & 13 & 12 & 12 \\
\hline
\end{tabular}


Table 7: IT Monetary Policy Regimes; Dependent Variable: Number of Net Easings of Outflows

\begin{tabular}{|c|c|c|c|c|c|c|c|c|c|c|c|}
\hline & (1) & (2) & (3) & (4) & (5) & (6) & (7) & (8) & (9) & (10) & (11) \\
\hline Free Floating Exchange Rate & -0.14 & -0.07 & -0.06 & -0.07 & -0.05 & -0.07 & -0.03 & -0.13 & -0.05 & -0.07 & -0.10 \\
\hline Regime & $(0.16)$ & $(0.16)$ & $(0.17)$ & $(0.17)$ & $(0.17)$ & $(0.16)$ & $(0.16)$ & $(0.16)$ & $(0.17)$ & $(0.19)$ & $(0.19)$ \\
\hline No. of Net Tightenings of & -0.06 & -0.07 & -0.07 & -0.07 & -0.06 & -0.08 & -0.06 & -0.08 & -0.07 & -0.08 & -0.08 \\
\hline Inflow Controls & $(0.09)$ & $(0.08)$ & $(0.08)$ & $(0.08)$ & $(0.07)$ & $(0.08)$ & $(0.10)$ & $(0.09)$ & $(0.09)$ & $(0.09)$ & $(0.09)$ \\
\hline Capital Account Openness & $-0.38 * *$ & $-0.40 * *$ & $-0.41 * *$ & $-0.42 * *$ & $-0.49 * * *$ & $-0.47 * * *$ & -0.26 & $-0.45^{* *}$ & $-0.37 * *$ & $-0.38 * *$ & $-0.38 * *$ \\
\hline (Chinn-Ito) & $(0.14)$ & $(0.16)$ & $(0.16)$ & $(0.15)$ & $(0.15)$ & $(0.14)$ & $(0.15)$ & $(0.16)$ & $(0.14)$ & $(0.15)$ & $(0.14)$ \\
\hline \multicolumn{12}{|l|}{ Fiscal Concerns } \\
\hline 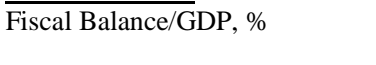 & $\begin{array}{l}0.18^{*} \\
(0.08)\end{array}$ & $\begin{array}{l}0.19 * * \\
(0.07)\end{array}$ & $\begin{array}{l}0.19 * * \\
(0.07)\end{array}$ & $\begin{array}{l}0.19 * * \\
(0.07)\end{array}$ & $\begin{array}{l}0.17^{* *} \\
(0.07)\end{array}$ & $\begin{array}{l}0.19 * * \\
(0.07)\end{array}$ & $\begin{array}{l}0.17^{*} \\
(0.08)\end{array}$ & $\begin{array}{l}0.16^{*} \\
(0.09)\end{array}$ & $\begin{array}{l}0.15 \\
(0.08)\end{array}$ & $\begin{array}{l}0.15 \\
(0.08)\end{array}$ & $\begin{array}{l}0.15 \\
(0.08)\end{array}$ \\
\hline Liquidation Tax & 0.05 & 0.01 & 0.05 & 0.05 & 0.06 & 0.05 & 0.10 & 0.02 & 0.08 & 0.10 & -0.06 \\
\hline & $(0.14)$ & $(0.13)$ & $(0.14)$ & $(0.14)$ & $(0.13)$ & $(0.13)$ & $(0.13)$ & $(0.10)$ & $(0.11)$ & $(0.10)$ & $(0.16)$ \\
\hline Repression Revenues/GDP, \% & $\begin{array}{l}-0.14 \\
(0.10)\end{array}$ & & & & & & & $\begin{array}{l}-0.06 \\
(0.13)\end{array}$ & & & \\
\hline (Bank Lending to Govt./Bank & & 0.13 & & & & & & 0.01 & & & \\
\hline Assets)*Inflation & & $(0.17)$ & & & & & & $(0.17)$ & & & \\
\hline NKI Concerns & & & & & & & & & & & \\
\hline Change in Stock Prices, (\% yoy) & $\begin{array}{l}0.11^{*} \\
(0.06)\end{array}$ & $\begin{array}{l}0.11^{* *} \\
(0.04)\end{array}$ & $\begin{array}{l}0.11 * * \\
(0.04)\end{array}$ & $\begin{array}{l}0.11 * * \\
(0.04)\end{array}$ & $\begin{array}{l}0.13 * * * \\
(0.04)\end{array}$ & $\begin{array}{l}0.11 * * * \\
(0.03)\end{array}$ & $\begin{array}{l}0.12 * * \\
(0.04)\end{array}$ & $\begin{array}{l}0.12 * * \\
(0.05)\end{array}$ & $\begin{array}{l}0.13^{* * * *} \\
(0.04)\end{array}$ & $\begin{array}{l}0.14^{* *} \\
(0.05)\end{array}$ & $\begin{array}{l}0.14 * * \\
(0.05)\end{array}$ \\
\hline Gross Inflow Stop & $\begin{array}{l}-0.19 \\
(0.11)\end{array}$ & $\begin{array}{l}-0.21 \\
(0.11)\end{array}$ & $\begin{array}{l}-0.19 \\
(0.12)\end{array}$ & $\begin{array}{l}-0.18 \\
(0.13)\end{array}$ & $\begin{array}{l}-0.25^{*} \\
(0.12)\end{array}$ & $\begin{array}{l}-0.23 \\
(0.14)\end{array}$ & $\begin{array}{l}-0.20^{*} \\
(0.11)\end{array}$ & $\begin{array}{l}-0.22 \\
(0.15)\end{array}$ & $\begin{array}{l}-0.25 \\
(0.14)\end{array}$ & $\begin{array}{l}-0.15 \\
(0.15)\end{array}$ & $\begin{array}{l}-0.16 \\
(0.15)\end{array}$ \\
\hline Flight & $\begin{array}{l}-0.04 \\
(0.10)\end{array}$ & $\begin{array}{l}-0.01 \\
(0.11)\end{array}$ & $\begin{array}{l}-0.01 \\
(0.10)\end{array}$ & $\begin{array}{l}-0.02 \\
(0.11)\end{array}$ & $\begin{array}{l}-0.07 \\
(0.12)\end{array}$ & $\begin{array}{l}-0.01 \\
(0.12)\end{array}$ & $\begin{array}{l}-0.02 \\
(0.10)\end{array}$ & $\begin{array}{l}-0.05 \\
(0.12)\end{array}$ & $\begin{array}{l}-0.04 \\
(0.11)\end{array}$ & $\begin{array}{l}-0.01 \\
(0.13)\end{array}$ & $\begin{array}{l}0.00 \\
(0.14)\end{array}$ \\
\hline REER Volatility & $\begin{array}{l}-0.11 \\
(0.11)\end{array}$ & $\begin{array}{l}-0.11 \\
(0.12)\end{array}$ & $\begin{array}{l}-0.10 \\
(0.12)\end{array}$ & $\begin{array}{l}-0.11 \\
(0.11)\end{array}$ & $\begin{array}{l}-0.08 \\
(0.14)\end{array}$ & $\begin{array}{l}-0.18^{* *} \\
(0.08)\end{array}$ & $\begin{array}{l}-0.04 \\
(0.09)\end{array}$ & $\begin{array}{l}-0.19^{*} \\
(0.09)\end{array}$ & $\begin{array}{l}-0.13 \\
(0.08)\end{array}$ & $\begin{array}{l}-0.13 \\
(0.08)\end{array}$ & $\begin{array}{l}-0.12 \\
(0.08)\end{array}$ \\
\hline NKI Volatility & $\begin{array}{l}-0.24 \\
(0.16)\end{array}$ & $\begin{array}{l}-0.43^{* *} \\
(0.17)\end{array}$ & $\begin{array}{l}-0.45^{* *} \\
(0.18)\end{array}$ & $\begin{array}{l}-0.45^{* *} \\
(0.17)\end{array}$ & $\begin{array}{l}-0.43^{* *} \\
(0.18)\end{array}$ & $\begin{array}{l}-0.43^{* *} \\
(0.16)\end{array}$ & $\begin{array}{l}-0.40^{* * *} \\
(0.12)\end{array}$ & $\begin{array}{l}-0.29 * \\
(0.15)\end{array}$ & $\begin{array}{l}-0.39^{* * *} \\
(0.11)\end{array}$ & $\begin{array}{l}-0.42^{* * *} \\
(0.12)\end{array}$ & $\begin{array}{l}-0.35^{* *} \\
(0.15)\end{array}$ \\
\hline NKI/GDP, \% & & & $\begin{array}{l}0.01 \\
(0.09)\end{array}$ & & & & & $\begin{array}{l}0.03 \\
(0.09)\end{array}$ & $\begin{array}{l}-0.01 \\
(0.09)\end{array}$ & $\begin{array}{l}-0.02 \\
(0.09)\end{array}$ & $\begin{array}{l}-0.02 \\
(0.08)\end{array}$ \\
\hline EMP & & & & $\begin{array}{l}-0.09 \\
(0.08)\end{array}$ & & & & $\begin{array}{l}-0.13^{* *} \\
(0.05)\end{array}$ & $\begin{array}{l}-0.13^{* *} \\
(0.04)\end{array}$ & $\begin{array}{l}-0.12^{* *} \\
(0.04)\end{array}$ & $\begin{array}{l}-0.11^{* *} \\
(0.04)\end{array}$ \\
\hline$\Delta$ (Reserves/GDP, \%) & & & & & $\begin{array}{l}-0.14 \\
(0.13)\end{array}$ & & & $\begin{array}{l}-0.08 \\
(0.15)\end{array}$ & $\begin{array}{l}-0.10 \\
(0.14)\end{array}$ & $\begin{array}{l}-0.08 \\
(0.14)\end{array}$ & $\begin{array}{l}-0.07 \\
(0.14)\end{array}$ \\
\hline REER Appreciation & & & & & & $\begin{array}{l}0.10 \\
(0.06)\end{array}$ & & $\begin{array}{l}0.08 \\
(0.06)\end{array}$ & $\begin{array}{l}0.08 \\
(0.05)\end{array}$ & $\begin{array}{l}0.09 \\
(0.06)\end{array}$ & $\begin{array}{l}0.09 \\
(0.06)\end{array}$ \\
\hline (Short Term External Debt- & & & & & & & $-0.40^{* *}$ & & $-0.37 * * *$ & $-0.36^{* * *}$ & $-0.31 * *$ \\
\hline $\begin{array}{l}\text { Reserves)/GDP, \% } \\
\text { Real GDP Growth, (\% yoy) }\end{array}$ & & & & & & & $(0.14)$ & & $(0.11)$ & $\begin{array}{l}(0.11) \\
0.12 \\
(0.12)\end{array}$ & $\begin{array}{l}(0.11) \\
0.13 \\
(0.12)\end{array}$ \\
\hline Trade/GDP, \% & & & & & & & & & & $\begin{array}{l}-0.13 \\
(0.22)\end{array}$ & $\begin{array}{l}-0.23 \\
(0.23)\end{array}$ \\
\hline $\begin{array}{l}\text { Inflation, \% } \\
\text { (External Debt-Reserves)/GDP, } \\
\%\end{array}$ & & & & & & & & & & & 0.20 \\
\hline Observations & 293 & 317 & 317 & 317 & 317 & 317 & 293 & 293 & 293 & 293 & 293 \\
\hline R-squared & 0.26 & 0.23 & 0.23 & 0.24 & 0.24 & 0.24 & 0.27 & 0.28 & 0.29 & 0.30 & 0.30 \\
\hline Number of Countries & 10 & 11 & 11 & 11 & 11 & 11 & 10 & 10 & 10 & 10 & 10 \\
\hline
\end{tabular}

number of easings/tightenings, have been normalized and outliers have been removed. 
Table 8: Non-IT Monetary Policy Regimes; Dependent Variable: Number of Net Easings of Outflows

\begin{tabular}{|c|c|c|c|c|c|c|c|c|c|c|c|c|}
\hline & (1) & $(2)$ & (3) & (4) & (5) & (6) & (7) & $(8)$ & (9) & $(10)$ & (11) & $(12)$ \\
\hline Free Floating Exchange Rate & -0.46 & -0.32 & -0.40 & -0.30 & -1.69 & -1.01 & -0.80 & -0.43 & -2.06 & -1.67 & -2.05 & -2.65 \\
\hline Regime & $(0.34)$ & $(0.47)$ & $(0.28)$ & $(0.53)$ & $(1.07)$ & $(0.77)$ & $(0.43)$ & $(0.52)$ & $(1.41)$ & $(1.27)$ & $(1.37)$ & (1.53) \\
\hline No. of Net Tightenings of & 0.17 & 0.19 & 0.19 & 0.19 & 0.24 & 0.20 & 0.22 & 0.20 & 0.24 & 0.21 & 0.24 & 0.27 \\
\hline Inflow Controls & $(0.13)$ & $(0.16)$ & $(0.15)$ & $(0.16)$ & $(0.18)$ & $(0.17)$ & $(0.16)$ & $(0.17)$ & $(0.18)$ & $(0.17)$ & $(0.19)$ & $(0.19)$ \\
\hline Capital Account Openness & -0.76 & -0.67 & -0.65 & -0.70 & -0.39 & -0.69 & -0.87 & -0.83 & -0.79 & $-1.09 *$ & -0.47 & -0.35 \\
\hline (Chinn-Ito) & $(0.53)$ & $(0.68)$ & $(0.57)$ & $(0.60)$ & $(0.51)$ & $(0.63)$ & $(0.68)$ & $(0.61)$ & $(0.63)$ & $(0.54)$ & $(0.40)$ & $(0.38)$ \\
\hline \\
\hline 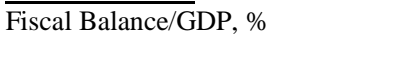 & $\begin{array}{l}0.05^{*} \\
(0.03)\end{array}$ & $\begin{array}{l}0.13^{*} \\
(0.07)\end{array}$ & $\begin{array}{l}0.11 \\
(0.07)\end{array}$ & $\begin{array}{l}0.13 \\
(0.07)\end{array}$ & $\begin{array}{l}-0.06 \\
(0.24)\end{array}$ & $\begin{array}{l}0.16^{* *} \\
(0.05)\end{array}$ & $\begin{array}{l}0.13^{*} \\
(0.06)\end{array}$ & $\begin{array}{l}0.12 \\
(0.07)\end{array}$ & $\begin{array}{l}-0.13 \\
(0.19)\end{array}$ & $\begin{array}{l}-0.17 \\
(0.18)\end{array}$ & $\begin{array}{l}-0.03 \\
(0.22)\end{array}$ & $\begin{array}{l}-0.07 \\
(0.20)\end{array}$ \\
\hline Liquidation Tax & $\begin{array}{l}0.46^{* * *} \\
(0.10)\end{array}$ & $\begin{array}{l}0.35 \\
(0.34)\end{array}$ & $\begin{array}{l}0.38 \\
(0.29)\end{array}$ & $\begin{array}{l}0.39 \\
(0.31)\end{array}$ & $\begin{array}{l}0.02 \\
(0.19)\end{array}$ & $\begin{array}{l}0.47 \\
(0.29)\end{array}$ & $\begin{array}{l}0.35 \\
(0.28)\end{array}$ & $\begin{array}{l}0.34 \\
(0.26)\end{array}$ & $\begin{array}{l}0.70^{*} \\
(0.29)\end{array}$ & $\begin{array}{l}1.31^{* *} \\
(0.46)\end{array}$ & $\begin{array}{l}0.11 \\
(0.24)\end{array}$ & $\begin{array}{l}1.09 \\
(0.96)\end{array}$ \\
\hline Repression Revenues/GDP, \% & $\begin{array}{l}-0.41 \\
(0.31)\end{array}$ & & & & & & & & $\begin{array}{l}-0.22 \\
(0.26)\end{array}$ & $\begin{array}{l}-0.25 \\
(0.23)\end{array}$ & & \\
\hline $\begin{array}{l}\text { (Bank Lending to Govt./Bank } \\
\text { Assets)*Inflation }\end{array}$ & & $\begin{array}{l}0.07 \\
(0.25)\end{array}$ & & & & & & & $\begin{array}{l}-0.64 \\
(0.34)\end{array}$ & $\begin{array}{l}-1.51^{*} \\
(0.65)\end{array}$ & & \\
\hline \multicolumn{13}{|l|}{ NKI Concerns } \\
\hline Change in Stock Prices, (\% yoy) & $\begin{array}{l}0.04 \\
(0.22)\end{array}$ & $\begin{array}{l}0.16 \\
(0.23)\end{array}$ & $\begin{array}{l}0.14 \\
(0.20)\end{array}$ & $\begin{array}{l}0.17 \\
(0.25)\end{array}$ & $\begin{array}{l}0.14 \\
(0.18)\end{array}$ & $\begin{array}{l}0.19 \\
(0.21)\end{array}$ & $\begin{array}{l}0.18 \\
(0.26)\end{array}$ & $\begin{array}{l}0.22 \\
(0.24)\end{array}$ & $\begin{array}{l}0.04 \\
(0.24)\end{array}$ & $\begin{array}{l}0.10 \\
(0.21)\end{array}$ & $\begin{array}{l}0.16 \\
(0.22)\end{array}$ & $\begin{array}{l}0.01 \\
(0.35)\end{array}$ \\
\hline Gross Inflow Stop & $\begin{array}{l}-0.11 \\
(0.32)\end{array}$ & $\begin{array}{l}-0.28 \\
(0.26)\end{array}$ & $\begin{array}{l}-0.27 \\
(0.19)\end{array}$ & $\begin{array}{l}-0.28 \\
(0.35)\end{array}$ & $\begin{array}{l}0.03 \\
(0.21)\end{array}$ & $\begin{array}{l}-0.31 \\
(0.24)\end{array}$ & $\begin{array}{l}-0.71^{*} \\
(0.36)\end{array}$ & $\begin{array}{l}-0.60^{*} \\
(0.28)\end{array}$ & $\begin{array}{l}-0.32 \\
(0.85)\end{array}$ & $\begin{array}{l}-0.47 \\
(0.41)\end{array}$ & $\begin{array}{l}-0.24 \\
(0.37)\end{array}$ & $\begin{array}{l}-0.38 \\
(0.85)\end{array}$ \\
\hline Flight & $\begin{array}{l}-0.19 \\
(0.17)\end{array}$ & $\begin{array}{l}-0.02 \\
(0.28)\end{array}$ & $\begin{array}{l}0.01 \\
(0.27)\end{array}$ & $\begin{array}{l}-0.02 \\
(0.27)\end{array}$ & $\begin{array}{l}0.15 \\
(0.40)\end{array}$ & $\begin{array}{l}-0.05 \\
(0.28)\end{array}$ & $\begin{array}{l}-0.06 \\
(0.27)\end{array}$ & $\begin{array}{l}-0.11 \\
(0.29)\end{array}$ & $\begin{array}{l}-0.32 \\
(0.18)\end{array}$ & $\begin{array}{l}-0.57 * * \\
(0.20)\end{array}$ & $\begin{array}{l}0.03 \\
(0.45)\end{array}$ & $\begin{array}{l}-0.04 \\
(0.18)\end{array}$ \\
\hline REER Volatility & $\begin{array}{l}0.36^{*} \\
(0.16)\end{array}$ & $\begin{array}{l}0.22 \\
(0.17)\end{array}$ & $\begin{array}{l}0.30 * * \\
(0.12)\end{array}$ & $\begin{array}{l}0.22 \\
(0.17)\end{array}$ & $\begin{array}{l}0.28^{*} \\
(0.13)\end{array}$ & $\begin{array}{l}0.27 \\
(0.18)\end{array}$ & $\begin{array}{l}0.26 \\
(0.17)\end{array}$ & $\begin{array}{l}0.51^{* *} \\
(0.19)\end{array}$ & $\begin{array}{l}0.42 \\
(0.22)\end{array}$ & $\begin{array}{l}0.80^{* * *} \\
(0.26)\end{array}$ & $\begin{array}{l}0.48^{*} \\
(0.22)\end{array}$ & $\begin{array}{l}0.39 \\
(0.22)\end{array}$ \\
\hline NKI Volatility & $\begin{array}{l}-0.70^{* *} \\
(0.27)\end{array}$ & $\begin{array}{l}-0.44 \\
(0.45)\end{array}$ & $\begin{array}{l}-0.62 \\
(0.41)\end{array}$ & $\begin{array}{l}-0.45 \\
(0.47)\end{array}$ & $\begin{array}{l}-0.21 \\
(0.40)\end{array}$ & $\begin{array}{l}-0.49 \\
(0.45)\end{array}$ & $\begin{array}{l}-0.27 \\
(0.53)\end{array}$ & $\begin{array}{l}-0.24 \\
(0.49)\end{array}$ & $\begin{array}{l}-0.48 \\
(0.43)\end{array}$ & $\begin{array}{l}-0.42 \\
(0.40)\end{array}$ & $\begin{array}{l}-0.21 \\
(0.49)\end{array}$ & $\begin{array}{l}-0.67 \\
(0.65)\end{array}$ \\
\hline NKI/GDP, \% & & & $\begin{array}{l}0.25^{*} \\
(0.11)\end{array}$ & & & & & & $\begin{array}{l}-0.13 \\
(0.28)\end{array}$ & $\begin{array}{l}-0.37 \\
(0.30)\end{array}$ & $\begin{array}{l}0.04 \\
(0.20)\end{array}$ & $\begin{array}{l}-0.06 \\
(0.33)\end{array}$ \\
\hline EMP & & & & $\begin{array}{l}-0.02 \\
(0.14)\end{array}$ & & & & & $\begin{array}{l}-0.01 \\
(0.20)\end{array}$ & $\begin{array}{l}-0.05 \\
(0.19)\end{array}$ & $\begin{array}{l}0.05 \\
(0.16)\end{array}$ & $\begin{array}{l}-0.00 \\
(0.16)\end{array}$ \\
\hline$\Delta$ (Reserves/GDP, \%) & & & & & $\begin{array}{l}0.26^{* * *} \\
(0.07)\end{array}$ & & & & $\begin{array}{l}0.16 \\
(0.13)\end{array}$ & $\begin{array}{l}0.23^{*} \\
(0.10)\end{array}$ & $\begin{array}{l}0.21^{*} \\
(0.10)\end{array}$ & $\begin{array}{l}0.17 \\
(0.17)\end{array}$ \\
\hline REER Appreciation & & & & & & $\begin{array}{l}-0.20 \\
(0.13)\end{array}$ & & & $\begin{array}{l}-0.14 \\
(0.14)\end{array}$ & $\begin{array}{l}-0.11 \\
(0.13)\end{array}$ & $\begin{array}{l}-0.14 \\
(0.09)\end{array}$ & $\begin{array}{l}-0.09 \\
(0.12)\end{array}$ \\
\hline $\begin{array}{l}\text { (Short Term External Debt- } \\
\text { Reserves)/GDP, \% }\end{array}$ & & & & & & & $\begin{array}{l}-0.59 \\
(0.33)\end{array}$ & & $\begin{array}{l}-0.44 \\
(0.54)\end{array}$ & & & \\
\hline Real GDP Growth, (\% yoy) & & & & & & & & & & & & $\begin{array}{l}0.21 \\
(0.24)\end{array}$ \\
\hline Trade/GDP, \% & & & & & & & & & & & & $\begin{array}{l}1.80 \\
(1.20)\end{array}$ \\
\hline Inflation, \% & & & & & & & & & & & & $\begin{array}{l}-0.94 \\
(1.00)\end{array}$ \\
\hline (External Debt-Reserves)/GDP, \% & & & & & & & & $\begin{array}{l}-0.71^{*} \\
(0.32)\end{array}$ & & $\begin{array}{l}-0.95^{* *} \\
(0.38)\end{array}$ & $\begin{array}{l}-0.39 * \\
(0.19)\end{array}$ & $\begin{array}{l}-0.35 \\
(0.19)\end{array}$ \\
\hline Observations & 136 & 139 & 139 & 139 & 123 & 139 & 139 & 139 & 120 & 120 & 123 & 115 \\
\hline R-squared & 0.35 & 0.31 & 0.32 & 0.31 & 0.35 & 0.31 & 0.32 & 0.33 & 0.39 & 0.40 & 0.36 & 0.41 \\
\hline Number of Countries & 7 & 7 & 7 & 7 & 7 & 7 & 7 & 7 & 7 & 7 & 7 & 6 \\
\hline
\end{tabular}

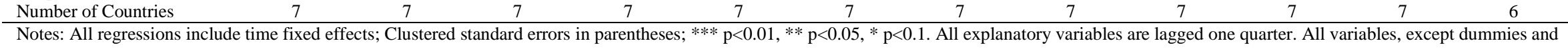
number of easings/tightenings, have been normalized and outliers have been removed. 


\section{Appendix}

\section{A. Measures on the capital account and their classification}

The database on capital controls measures is an extended version of the data collected in Pasricha (2012). It includes information on the "capital transactions" category of the IMF AREAER, supplemented by information on similar measures from central banks' and other country regulators' websites, news sources and other research papers. The IMF AREAER breaks down the broad category, capital transactions, as follows:

1. Controls on capital and money market instruments:

a. Controls on capital market securities: further classified into "controls on shares or other securities of a participating nature" and "banks or other debt securities"

b. Controls on money market instruments

c. Controls on collective investment schemes

2. Controls on derivatives and other instruments

3. Controls on Credit Operations:

a. Commercial Credits

b. Financial Credits

c. Guarantees, sureties and financial backup facilities

4. Controls on direct investment

5. Controls on liquidation of direct investment

6. Controls on real estate transactions

7. Controls on personal capital transactions

8. Provisions specific to the financial sector:

a. Provisions specific to commercial banks and other credit institutions, which include open foreign exchange position limits and other provisions

b. Provisions specific to institutional investors

A change is counted as a change in policy affecting one of the above eight categories. If a major policy announcement takes place and includes measures related to several categories above, each measure is classified in each category in which it belongs and is counted separately.

We classify the measures into the following categories:

1. Whether the measure (or change) impacts capital inflows (I) or outflows (O) or cannot be clearly identified as affecting only one of these categories (other). ${ }^{25,26}$ For the purpose of this paper, the 'other' measures are classified as both outflows and inflow controls.

\footnotetext{
${ }^{25}$ In this paper, capital inflow controls refer to controls on inflows by non-residents (including controls on repatriation of non-residents' inward investments) and controls on outflows refers to controls on outflows by residents, including on repatriation of outward investments. An alternative way to define capital outflow controls would group controls on outflows by residents and repatriation of non-residents' investment together. In general, tightening of repatriation restrictions for non-residents' investments already brought in (retroactive restrictions) is rare in non-crisis periods. Therefore, this distinction would be meaningful in our sample only for Argentina's post2001 controls. For this reason, we dropped Argentina's pre-2003 data in the analysis.

${ }^{26}$ Examples of the other measures that could not be classified as inflow or outflow measures include limits on net open foreign exchange positions of financial institutions, bans on use of foreign currency in special economic zones,
} 
2. Whether the change represents an easing (E) or tightening (T) of policy or a neutral/ institutional change.

\section{B. Computation of External Repression Revenues}

\section{Table A.1: Repression Revenues computations and formulas}

\begin{tabular}{|c|c|c|c|}
\hline \# & Variable & Descriptions and Source & Frequency \\
\hline 1 & $\begin{array}{l}\text { Total interest on } \\
\text { external public and } \\
\text { publicly guaranteed } \\
\text { (PPG) debt from } \\
\text { private creditors }\end{array}$ & $\begin{array}{l}\text { Interest payments on external PPG debt from private } \\
\text { creditors + change in interest arrears to private creditors, in } \\
\text { USD amounts. Several adjustments are made, in addition: } \\
\text { 1. WDI debt statistics on interest arrears are available only } \\
\text { for total interest arrears on PPG debt (i.e. not interest arrears } \\
\text { on PPG debt from private creditors) and total interest arrears } \\
\text { from official creditors. Under the assumption that all official } \\
\text { creditor arrears are on PPG debt, we first compute interest } \\
\text { arrears on PPG debt from private creditors as the difference } \\
\text { between total interest arrears on PPG debt and interest } \\
\text { arrears on debt from official creditors. } \\
\text { 2. The change in arrears is then adjusted for interest } \\
\text { forgiveness as part of sovereign commercial restructurings. } \\
\text { Now, again, interest rescheduled and forgiven is avaiable } \\
\text { only for all external debt (not just PPG debt). Therefore, we } \\
\text { took the dates of sovereign commercial restructurings from } \\
\text { Das et al. (2012) and added back to the change in interest } \\
\text { arrears the interest rescheduled or forgiven only for years in } \\
\text { which there was a sovereign restructuring with private } \\
\text { creditors. } \\
\text { 3. For India, the external interest payments in } 2003 \text { and } \\
2005 \text { jumped as they included the interest accrued over } 5 \\
\text { years but paid at maturity, for Resurgent India Bonds and } \\
\text { Millenium India Deposits. The interest payments for RIB } \\
\text { amounted to USD } 1 \text { billion in } 2003 \text { and for MID to USD } 1.6 \\
\text { billion in } 2005 \text { (Source: RBI report on India's external debt, } \\
\text { various issues). These amounts were deleted from } 2003 \text { and } \\
2005 \text { interest payments and re-allocated proportionately } \\
\text { over the 5-year term of each of these borrowings. Source: } \\
\text { World Bank WDI }\end{array}$ & Annual \\
\hline
\end{tabular}

restrictions on transactions that would constitute at once an inflow and outflow, for example use of external borrowing to invest abroad, etc. 
Table A.1 (contd.): Repression Revenues computations and formulas

\begin{tabular}{|c|c|c|c|}
\hline \# & Variable & Descriptions and Source & Frequency \\
\hline 2 & $\begin{array}{l}\text { External PPG debt } \\
\text { outstanding and } \\
\text { disbursed, from } \\
\text { private creditors }\end{array}$ & In USD. Source: World Bank WDI & Annual \\
\hline 3 & $\begin{array}{l}\text { Interest rate on } \\
\text { external debt }\end{array}$ & $\# 1$ divided by $(\# 2(t)+\# 2(t-1)) / 2$, expressed as \% per annum. & Annual \\
\hline 4 & Exchange rate & Local Currency Units (LCU) per USD, period average & Annual \\
\hline 5 & $\begin{array}{l}\text { Depreciation of } \\
\text { exchange rate }\end{array}$ & $(\# 4(\mathrm{t})-\# 4(\mathrm{t}-1)) * 100 / \# 4(\mathrm{t}-1)$ & Annual \\
\hline 6 & $\begin{array}{l}\text { Effective interest } \\
\text { rate on external debt }\end{array}$ & $\# 3\left(1+\# 5^{*} .01\right)$ & Annual \\
\hline 7 & $\begin{array}{l}\text { Net flow of PPG } \\
\text { debt from private } \\
\text { creditors, in USD }\end{array}$ & $\begin{array}{l}\text { These are also adjusted for debt forgiveness, as in \#1. } \\
\text { Source: World Bank WDI }\end{array}$ & Annual \\
\hline 8 & $\begin{array}{l}\text { USD revaluation } \\
\text { costs }\end{array}$ & $\begin{array}{l}\text { This variable captures the impact of change in value of debt } \\
\text { denominated in non-domestic and non-USD currencies, due } \\
\text { to the revaluation of domestic currency against USD and the } \\
\text { revaluation of USD against these currencies. It is computed } \\
\text { as: (\#2(t)-\#2(t-1) - \#7)*100/\#2(t-1) }\end{array}$ & Annual \\
\hline 9 & $\begin{array}{l}\text { Effective interest } \\
\text { rate on external debt, } \\
\text { including debt } \\
\text { revaluation costs }\end{array}$ & $\begin{array}{l}\text { This measure uses the Giovannini and de Melo formula } \\
\text { exactly: } \# 3+\# 5+\# 8\end{array}$ & Annual \\
\hline 10 & $\begin{array}{l}\text { Domestic interest } \\
\text { payments }\end{array}$ & in LCU. Country sources, see country sources in Table A.2 & $\begin{array}{l}\text { Annual/ } \\
\text { Quarterly }\end{array}$ \\
\hline 11 & $\begin{array}{l}\text { Total domestic debt } \\
\text { outstanding }\end{array}$ & in LCU. Country sources, see country sources in Table A.2 & $\begin{array}{l}\text { Annual/ } \\
\text { Quarterly }\end{array}$ \\
\hline 12 & $\begin{array}{l}\text { Total domestic debt } \\
\text { outstanding } \\
\text { (excluding debt held } \\
\text { by monetary } \\
\text { authorities) }\end{array}$ & $\begin{array}{l}\text { \#12 less debt held by monetary authorities, which is IFS } \\
\text { series FASAG or 12A. }\end{array}$ & $\begin{array}{l}\text { Annual/ } \\
\text { Quarterly }\end{array}$ \\
\hline 13 & $\begin{array}{l}\text { Domestic interest } \\
\text { rate }\end{array}$ & $\# 10 /(\# 11(\mathrm{t})+\# 11(\mathrm{t}-1) / 2)$, expressed as $\%$ pa & $\begin{array}{l}\text { Annual/ } \\
\text { Quarterly }\end{array}$ \\
\hline 14 & $\begin{array}{l}\text { Repression revenue } \\
\text { (or external } \\
\text { repression revenue) }\end{array}$ & $\begin{array}{l}\text { (Effective external interest rate - domestic interest } \\
\text { rate)*domestic debt outstanding (excluding debt held by } \\
\text { monetary authorities). i.e. (\#6-\#13)*12 }\end{array}$ & $\begin{array}{l}\text { Annual/ } \\
\text { Quarterly }\end{array}$ \\
\hline 15 & $\begin{array}{l}\text { Repression revenue } \\
\text { (including debt } \\
\text { revaluation costs) }\end{array}$ & $(\# 9-\# 13)^{* \# 12}$ & $\begin{array}{l}\text { Annual/ } \\
\text { Quarterly }\end{array}$ \\
\hline
\end{tabular}




\begin{tabular}{|c|c|c|c|}
\hline \# & Variable & Descriptions and Source & Frequency \\
\hline \multicolumn{4}{|c|}{ Components of Repression Revenues: } \\
\hline $16 a$ & $\begin{array}{l}\text { a. Interest } \\
\text { Differential }\end{array}$ & $\begin{array}{l}\text { External interest rate (in USD terms) - domestic interest } \\
\text { rate, i.e. \#3-\#12, expressed as \% per annum. To compute as } \\
\% \text { of GDP, the interest differential is multiplied by } \# 12 \text { and } \\
\text { divided by nominal GDP. }\end{array}$ & $\begin{array}{l}\text { Annual/ } \\
\text { Quarterly }\end{array}$ \\
\hline $16 b$ & $\begin{array}{l}\text { b. FX Rate } \\
\text { Component }\end{array}$ & $\begin{array}{l}\text { External interest rate*Depreciation of exchange rate, i.e. } \\
\# 3^{*} \# 5^{*} .01 \text {, \% pa. To compute as \% of GDP, the FX rate } \\
\text { component is multiplied by } \# 12 \text { and divided by nominal } \\
\text { GDP. }\end{array}$ & $\begin{array}{l}\text { Annual/ } \\
\text { Quarterly }\end{array}$ \\
\hline
\end{tabular}

\section{Table A.2: Country Sources for Domestic Interest and Domestic Debt}

\begin{tabular}{|c|c|c|c|}
\hline & \multicolumn{3}{|c|}{$\begin{array}{l}\text { Domestic interest at time } t\left(\mathrm{i}_{\mathrm{t}}\right) \text { is computed as (Series \#1) interest paid on domestic debt of government } t_{t} /\left(0.5^{*}\right. \\
\left.\text { (Series \#2)Gross domestic debt outstanding } \mathrm{t}_{t}+0.5^{*} \text { (Series \#2)Gross domestic debt outstanding } \mathrm{t}_{\mathrm{t}-1}\right)\end{array}$} \\
\hline & \multicolumn{3}{|c|}{ Variables, except interest rates, are in local currency units (LCU) unless otherwise specified. } \\
\hline & \multicolumn{3}{|c|}{ For quarterly data, the domestic interest is annualized by multiplying the above by 4 . } \\
\hline & \multicolumn{3}{|c|}{$\begin{array}{l}\text { In some cases, where the data starts in } 2001 \text { or later, the first observation uses gross domestic debt } \\
\text { outstanding at } t \text {, instead of the average of } t \text { and } t-1 \text {, to avoid losing the observation. }\end{array}$} \\
\hline & \multicolumn{3}{|c|}{$\begin{array}{l}\text { For Argentina, Peru and Turkey, quarterly, non-seasonally adjusted data on interest payments was available, } \\
\text { and displayed seasonality. The interest rate computed was smoothed by taking the 4-quarter moving average } \\
\text { of } \mathrm{i}_{\mathrm{t}} \text { (including time } \mathrm{t} \text { ). }\end{array}$} \\
\hline & Series Name & Sources/Definitions & $\begin{array}{l}\text { Original } \\
\text { Frequency }\end{array}$ \\
\hline & \multicolumn{3}{|l|}{ Argentina } \\
\hline 1 & $\begin{array}{l}\text { Current Outlays: Interest on Domestic Public } \\
\text { Debt }\end{array}$ & Haver & Quarterly \\
\hline 2.a & Gross Public Debt (USD) & Haver & Quarterly \\
\hline 2.b & End of period exchange rate against USD & $\begin{array}{l}\text { IMF International Financial Statistics } \\
\text { (IFS) }\end{array}$ & Quarterly \\
\hline 2.c & $\begin{array}{l}\text { Non-financial Public Sector and Central Bank } \\
\text { External Debt (USD) }\end{array}$ & Haver & \\
\hline \multirow[t]{4}{*}{2} & Domestic Public Debt Outstanding & $(\# 2 a-\# 2 c) * \# 2 . b$ & Quarterly \\
\hline & \multicolumn{3}{|l|}{ Brazil } \\
\hline & $\begin{array}{l}\text { Net public sector implicit interest rate on internal } \\
\text { debt }\end{array}$ & $\begin{array}{l}\text { Banco Central do Brasil. Quarterly data } \\
\text { are averages of monthly data available } \\
\text { from source. Due to data availability, } \\
\text { 2001-October } 2002 \text { include Perobras and } \\
\text { Electrobras, and the subsequent numbers } \\
\text { exclude these state owned enterprises. }\end{array}$ & Monthly \\
\hline & Gross Public Sector Domestic Debt & Banco Central do Brasil. & Monthly \\
\hline
\end{tabular}




\begin{tabular}{|c|c|c|c|}
\hline & Series Name & Sources/Definitions & $\begin{array}{l}\text { Original } \\
\text { Frequency }\end{array}$ \\
\hline & Chile & & \\
\hline 1.a & Central government expenditure: interest on debt & Haver; IFS & Annual \\
\hline 1.b & $\begin{array}{l}\text { General government (excluding Central Bank) } \\
\text { expenditure: interest on long term external debt } \\
\text { (USD) }\end{array}$ & Banco Central de Chile & Annual \\
\hline 1.c & Exchange rate against USD (Period Average) & IMF IFS & Annual \\
\hline 1 & Central Government Domestic Interest Rate & $(\# 1 . a-\# 1 . b)^{* \# 1 . c}$ & Annual \\
\hline \multirow[t]{2}{*}{2} & Central Government Gross Financial Debt & Haver & Annual \\
\hline & $\begin{array}{l}\text { Colombia } \\
\text { Average coupon on central government domestic } \\
\text { debt }\end{array}$ & Haver & Quarterly \\
\hline \multirow[t]{4}{*}{2} & $\begin{array}{l}\text { Central government (medium and long term) } \\
\text { domestic debt }\end{array}$ & Haver & Quarterly \\
\hline & $\begin{array}{l}\text { China } \\
\text { National Government expenditure: Treasury } \\
\text { Securities Domestic Interest }\end{array}$ & Haver/ Ministry of Finance & Annual \\
\hline & Central Government Gross Debt & Haver/ CNBS & Annual \\
\hline & Czech Republic & & \\
\hline 1 & State Debt -domestic Debt & Ministry of Finance & Annual \\
\hline \multirow[t]{2}{*}{2} & State Debt - Interest Costs & Ministry of Finance & Annual \\
\hline & Egypt & & \\
\hline 1 & Consolidated General Government Expenditure & Haver/Ministry of Finance & Annual \\
\hline \multirow[t]{2}{*}{2} & General Government Gross Domestic Debt & $\begin{array}{l}\text { Haver/Ministry of Finance; Available } \\
\text { every June from 2001-March } 2006 . \\
\text { Linearly interpolated for Q4 values. }\end{array}$ & Annual \\
\hline & India & & \\
\hline 1.a & Central Government Total Interest Payments & Ministry of Finance & Annual \\
\hline 1.b & Central Government External Interest Payments & Ministry of Finance & Annual \\
\hline 1 & Central Government Domestic Interest Payments & \#1.a-\#1.b & \\
\hline 2 & Central Government Total Internal Liabilities & $\begin{array}{l}\text { Reserve Bank of India } \\
\text { Note: all variables available for fiscal } \\
\text { year. Fiscal year values converted to } \\
\text { calendar year by taking } 1 / 4 \text { of previous } \\
\text { fiscal year and } 3 / 4 \text { of current fiscal year. }\end{array}$ & Annual \\
\hline & Indonesia & & \\
\hline
\end{tabular}




\begin{tabular}{|c|c|c|c|}
\hline & Series Name & Sources/Definitions & $\begin{array}{l}\text { Original } \\
\text { Frequency }\end{array}$ \\
\hline 1 & $\begin{array}{l}\text { Central Government Current Expenditure: Interest } \\
\text { Payments }\end{array}$ & Haver/DK & Annual \\
\hline \multirow[t]{3}{*}{2} & Central Government Domestic Debt & Haver/Bank of Indonesia & Monthly \\
\hline & Malaysia & & \\
\hline & $\begin{array}{l}\text { Federal Government Operating Expenditure: Debt } \\
\text { Service charges, domestic }\end{array}$ & Banka Negara Malaysia & Annual \\
\hline \multirow[t]{2}{*}{2} & Federal Government Total Domestic Debt & Banka Negara Malaysia & Annual \\
\hline & Mexico & & \\
\hline 1 & Public Sector domestic interest payments & Secretaria de Hacienda Credito Publico & \\
\hline \multirow[t]{2}{*}{2} & Public Sector domestic debt & Secretaria de Hacienda Credito Publico & \\
\hline & Peru & & \\
\hline 1 & Central Government Interest on Domestic Debt & Haver/BCRP & Quarterly \\
\hline 2.a & $\begin{array}{l}\text { Federal Government Domestic Gross Debt (NSA) } \\
\text { (USD) }\end{array}$ & Haver/BCRP & Quarterly \\
\hline 2.b & Exchange rate against USD (End of Period) & IFS & Quarterly \\
\hline \multirow[t]{2}{*}{2} & Federal government Gross Domestic Debt & \#2.a*\#2.b & Quarterly \\
\hline & Philippines & & \\
\hline 1 & $\begin{array}{l}\text { National government Current Operating } \\
\text { Expenditure: Interest Payments - domestic }\end{array}$ & Datastream & Quarterly \\
\hline \multirow[t]{2}{*}{2} & Central Government Domestic Debt & Oxford Economics & Annual \\
\hline & South Africa & & \\
\hline 1 & National government Interest on Domestic Debt & South Africa Treasury & Annual \\
\hline \multirow[t]{2}{*}{2} & National Government Gross Domestic Debt & Haver/ SARB & Quarterly \\
\hline & Turkey & & \\
\hline 1 & $\begin{array}{l}\text { Central Government Budget Expenses: Domestic } \\
\text { Interest }\end{array}$ & Central Bank of Turkey & Monthly \\
\hline 2 & Domestic Debt Position (Treasury) & Central Bank of Turkey & Monthly \\
\hline
\end{tabular}

\section{Data Appendix}

Table A3. Countries in Sample

\begin{tabular}{|llll|}
\hline Argentina & Egypt & Mexico & South Africa \\
Brazil & India & Morocco & Thailand \\
Chile & Indonesia & Peru & Turkey \\
China & Korea & Philippines & \\
Colombia & Malaysia & Russia & \\
\hline
\end{tabular}


Table A.4: Summary Statistics of Explanatory Variables

\begin{tabular}{|c|c|c|c|c|c|c|}
\hline & $\mathbf{N}$ & Minimum & Maximum & Median & Mean & $\begin{array}{l}\text { Standard } \\
\text { Deviation }\end{array}$ \\
\hline \multicolumn{7}{|l|}{ Fiscal Concerns } \\
\hline Fiscal Balance/Tax Revenues, \% & 656 & -138.33 & 94.98 & -10.86 & -13.36 & 31.54 \\
\hline Gross Govt. Debt/Tax Revenues, \% & 656 & 69.25 & 2817.58 & 879.11 & 980.76 & 610.38 \\
\hline Repression Revenues/GDP, \% & 501 & -5.56 & 7.64 & -0.14 & -0.19 & 1.49 \\
\hline $\begin{array}{l}\text { Repression Revenues (incl. debt revaluation } \\
\text { costs)/GDP, \% }\end{array}$ & 501 & -35.38 & 34.94 & -0.23 & -0.2 & 6.05 \\
\hline Liquidation Tax & 528 & -12.31 & 25.52 & -2.68 & -1.97 & 4.36 \\
\hline Real Deposit Rate & 707 & -15.75 & 14.47 & 1.04 & 1.09 & 4.15 \\
\hline (Bank Lending to Govt./Bank Assets)*Inflation & 707 & -13.85 & 36.2 & 0.95 & 1.75 & 3.47 \\
\hline \multicolumn{7}{|l|}{ Overheating Concerns } \\
\hline Domestic Credit Gap & 679 & -32.14 & 31.24 & -0.49 & -0.02 & 6.17 \\
\hline Domestic Credit/GDP Growth, (\% yoy) & 659 & 0.06 & 0.12 & 0.08 & 0.08 & 0.01 \\
\hline Inflation, \% & 707 & -2.79 & 47.04 & 4.39 & 5.7 & 4.96 \\
\hline Real GDP Growth, (\% yoy) & 695 & -14.74 & 16.09 & 5.31 & 5.13 & 3.72 \\
\hline Current Account Balance/GDP, \% & 596 & -7.23 & 19.47 & 0.56 & 1.53 & 4.6 \\
\hline NKI/GDP, \% & 675 & -26.12 & 12.62 & 1.54 & 1.06 & 3.98 \\
\hline \multicolumn{7}{|l|}{ FX Valuation Concerns } \\
\hline$\Delta$ (Reserves/GDP, \%) & 679 & -9.43 & 14.24 & 0.26 & 0.64 & 2.78 \\
\hline Exchange Market Pressure (EMP) & 707 & -0.73 & 0.93 & -0.05 & -0.06 & 0.14 \\
\hline Change in REER, (\% yoy) & 667 & -31.35 & 37.33 & 1.01 & 1.53 & 9.23 \\
\hline REER Deviation from Trend, \% & 667 & -46.15 & 34.56 & 0.35 & 0.74 & 12.57 \\
\hline PPP based Undervaluation & 747 & -0.52 & 0.86 & 0.16 & 0.18 & 0.27 \\
\hline \multicolumn{7}{|l|}{ Macroeconomic Stability } \\
\hline REAL GDP Growth Volatility & 697 & 0.01 & 10.64 & 1.94 & 2.52 & 1.9 \\
\hline REER Volatility & 667 & 1.76 & 40.49 & 6.14 & 7.8 & 5.86 \\
\hline Equity Returns Volatility & 747 & 0.62 & 93.18 & 11.32 & 15.66 & 13.73 \\
\hline NKI Volatility & 739 & 0 & 159.56 & 5.59 & 11.01 & 17.94 \\
\hline Gross Inflows Volatility & 707 & 0.44 & 127.08 & 6.88 & 13.02 & 18.46 \\
\hline Gross Outflows Volatility & 701 & 0.02 & 109.74 & 4.73 & 8.5 & 12.51 \\
\hline \multicolumn{7}{|l|}{ Financial Stability } \\
\hline Change in Stock Prices, (\% yoy) & 747 & -84.84 & 388.22 & 16.89 & 20.84 & 44.43 \\
\hline (External Debt-Reserves)/GDP, \% & 665 & -39.18 & 121.51 & 14.33 & 16.32 & 23.11 \\
\hline (Short Term External Debt-Reserves)/GDP, \% & 625 & -44.89 & 7.41 & -8.78 & -11.55 & 11.45 \\
\hline \multicolumn{7}{|l|}{ Others } \\
\hline Capital Account Openness (Quinn Index) & 707 & 12.5 & 100 & 50 & 60.87 & 23.58 \\
\hline Capital Account Openness (Chinn-Ito) & 707 & -1.86 & 2.46 & -0.11 & 0.12 & 1.22 \\
\hline No. of Net Tightenings of Inflow Controls & 747 & -11 & 12 & 0 & -0.12 & 1.19 \\
\hline Trade/GDP, \% & 669 & 19.94 & 348.34 & 56.89 & 72.82 & 45.71 \\
\hline
\end{tabular}


Table A.5: Data Sources for Explanatory Variables.

\begin{tabular}{|c|c|}
\hline Variable & Definition/Source \\
\hline \multicolumn{2}{|l|}{ Fiscal concerns: } \\
\hline Fiscal Balance (\% of Tax Revenues) & $\begin{array}{l}\text { Fiscal Balance (\% of GDP)/(Tax Revenues (\% of GDP)). Tax } \\
\text { Revenues (\% of GDP) are from World Bank WDI. }\end{array}$ \\
\hline Govt. Debt (\% of Tax Revenues) & $\begin{array}{l}\text { (Government gross debt/GDP)*100/(Tax Revenues (\% of } \\
\text { GDP)). Government gross debt is from Oxford Economics, Tax } \\
\text { Revenues (\% of GDP) are from WDI and nominal GDP is from } \\
\text { Haver. }\end{array}$ \\
\hline Liquidation Tax, \% & $\begin{array}{l}\text { Negative of the real interest rate on government domestic debt. } \\
\text { See Appendix Tables A. } 1 \text { and A. } 2 \text { for details on computation of } \\
\text { nominal interest rate on government domestic debt. Real interest } \\
\text { rate is computed from nominal rates by subtracting (yoy) CPI } \\
\text { inflation. }\end{array}$ \\
\hline Repression Revenues/GDP, \% & See appendix Tables A.1 and A.2 \\
\hline $\begin{array}{l}\text { Repression Revenues (including debt } \\
\text { Revaluation costs), as \% of GDP }\end{array}$ & See appendix Tables A.1 and A.3, and explanations in the text. \\
\hline Real interest rate on deposits, \% & $\begin{array}{l}\text { Nominal interest rate on bank deposits, less Inflation. The } \\
\text { interest rate data is from IFS. See "Inflation" entry below. }\end{array}$ \\
\hline $\begin{array}{l}\text { (Bank Lending to Govt./Bank Assets) * } \\
\text { Inflation }\end{array}$ & $\begin{array}{l}\text { (DomClaimsBanks- } \\
\text { ClaimsonPvtSecBanks)*100/DomClaimsBanks. } \\
\text { DomClaimsBanks is Domestic Claims of Banking Sector, IFS } \\
\text { series } 32 \text { or FDSAD. ClaimsonPvtSecBanks is Banking Sector's } \\
\text { claims on private sector, IFS series 32D. }\end{array}$ \\
\hline \multicolumn{2}{|l|}{ Overheating Concerns: } \\
\hline Domestic Credit/GDP Growth (yoy, \%) & $\begin{array}{l}\text { Year-on-year growth of Domestic Credit/GDP. Domestic Credit } \\
\text { is Domestic Claims of Banking Sector, IFS series } 32 \text { or } \\
\text { FDSAD. GDP is nominal GDP from Haver. }\end{array}$ \\
\hline Domestic Credit Gap, \% & $\begin{array}{l}\text { Domestic Credit/GDP divided by its 3-year lagged moving } \\
\text { average }\end{array}$ \\
\hline Inflation (\% yoy) & Year-on-year percentage change in CPI. Data is from IFS. \\
\hline Real GDP Growth (\% yoy) & Year-on-year growth of real GDP. Real GDP is from Haver. \\
\hline Current Account Balance/GDP, \% & $\begin{array}{l}\text { 4-quarter moving average of current account/4-quarter moving } \\
\text { average of nominal GDP, in percentage terms. Current account } \\
\text { data is from IFS and nominal GDP from Haver. }\end{array}$ \\
\hline NKI/GDP, \% & $\begin{array}{l}\text { Net capital inflows are the financial account balance, n.i.e. } \\
\text { (BPM6) series from IFS and are measured in USD. Nominal } \\
\text { GDP data is from Haver and in LCU. It is converted into USD } \\
\text { by using the period average exchange rate against USD from } \\
\text { IFS. since NKI and GDP data are non-seasonally adjusted, 4- } \\
\text { quarter moving average of NKI is divided by the 4-quarter } \\
\text { moving average of GDP (and expressed as percentage) to get } \\
\text { NKI/GDP. }\end{array}$ \\
\hline NKI surge & $\begin{array}{l}\text { Dummy for surge in NKI. Defined according to methodology } \\
\text { described in Forbes and Warnock (2011). 4-quarter moving sum } \\
\text { of quarterly NKI are first computed and year-on-year changes in } \\
\text { these 4-quarter sums are obtained. Surge episodes satisfy three } \\
\text { criteria: (1) current year-over-year changes in four-quarter NKI } \\
\text { is more than two standard deviations above the historic }\end{array}$ \\
\hline
\end{tabular}


Table A.5 (contd.): Data Sources for Explanatory Variables.

\begin{tabular}{|c|c|}
\hline Variable & Definition/Source \\
\hline & $\begin{array}{l}\text { average during at least one quarter of the episode; (2) the } \\
\text { episode is defined as lasting for all consecutive quarters for } \\
\text { which the year-over-year change in four-quarter NKI is more } \\
\text { than one standard deviation above the historical average; and (3) } \\
\text { the length of the episode is greater than one quarter. NKI data } \\
\text { are from IFS. }\end{array}$ \\
\hline \multicolumn{2}{|l|}{ FX Valuation Concerns: } \\
\hline $\begin{array}{l}\Delta \text { (Reserves/GDP, \%) (or Change in } \\
\text { Reserves/GDP (yoy)) }\end{array}$ & $\begin{array}{l}\text { Year-on year change in total reserves excluding gold/annualized } \\
\text { nominal GDP. Reserves excluding gold are in SDR, nominal } \\
\text { GDP is in local currency units, and is converted into SDR by } \\
\text { using end of period exchange rates. All series are from IFS. }\end{array}$ \\
\hline Exchange Market Pressure (EMP) & $\begin{array}{l}\text { Higher values indicate depreciation pressure. Computed as the } \\
\text { sum of two components: (i) quarter on quarter change in log of } \\
\text { average exchange rate against SDR (LCU per SDR) (ii) } \\
\text { Negative of the change in Reserves less gold (in SDR)/Reserve } \\
\text { Money (or Monetary Base). All series are from IFS. }\end{array}$ \\
\hline REER Appreciation (\% yoy) & $\begin{array}{l}\text { Percentage year-on-year change in REER. Positive values } \\
\text { indicate REER appreciation. REER data is from IFS }\end{array}$ \\
\hline REER deviation from trend (\%) & $\begin{array}{l}\text { (REER- 5-year moving average of REER)*100/5-year moving } \\
\text { average of REER. }\end{array}$ \\
\hline PPP based undervaluation, \% & $\begin{array}{l}\text { Difference between the log of PPP real exchange rate and its } \\
\text { predicted value. Following Rodrick (2008) a currency is } \\
\text { classified as undervalued if its PPP real exchange rate is higher } \\
\text { than } 1 \text { after taking into account the Balassa-Samuelson effect. } \\
\text { Two series were used to compute this series. PPP real exchange } \\
\text { rate is the Purchasing Power Parity over GDP in national } \\
\text { currency units per US dollar. GDP per capita is PPP converted } \\
\text { GDP per capita at } 2005 \text { constant prices (International dollar per } \\
\text { person). Both series are obtained from Penn World Table } 7.0 \text {. } \\
\text { Data for all available countries and periods was used to compute } \\
\text { PPP based undervaluation. }\end{array}$ \\
\hline \multicolumn{2}{|l|}{ Macroeconomic Stability: } \\
\hline Volatility of Real GDP Growth & $\begin{array}{l}\text { 3-year rolling standard deviation of year-on-year growth of real } \\
\text { GDP. The real GDP data is from Haver. }\end{array}$ \\
\hline REER Volatility & $\begin{array}{l}\text { 3-year rolling standard deviation of year-on-year change in Real } \\
\text { Effective Exchange Rate (REER). The REER data is quarterly } \\
\text { and sourced from IFS. }\end{array}$ \\
\hline Volatility of Equity Returns & $\begin{array}{l}\text { 3-year rolling standard deviation of total returns of broad stock } \\
\text { market equity index. Return indices are from Datastream. }\end{array}$ \\
\hline NKI Volatility & $\begin{array}{l}\text { 3-year rolling standard deviation of year-on-year change in } 4- \\
\text { quarter sums of NKI. The NKI data is from IFS. }\end{array}$ \\
\hline Gross Inflows Volatility & $\begin{array}{l}\text { 3-year rolling standard deviation of year-on-year change in } 4 \text { - } \\
\text { quarter sums of gross inflows (i.e. net inflows by non-residents). } \\
\text { The gross inflows data is from IFS (See Gross Inflows/GDP). }\end{array}$ \\
\hline
\end{tabular}


Table A.5 (contd.): Data Sources for Explanatory Variables.

\begin{tabular}{|c|c|}
\hline Variable & Definition/Source \\
\hline Gross Outflows Volatility & $\begin{array}{l}\text { 3-year rolling standard deviation of year-on-year change in 4- } \\
\text { quarter sums of gross outflows (i.e. net outflows by residents). } \\
\text { The gross outflows data is from IFS (See Gross Outflows/GDP). }\end{array}$ \\
\hline \multicolumn{2}{|l|}{ Financial Stability: } \\
\hline (External Debt - Reserves)/GDP, \% & $\begin{array}{l}\text { Gross external debt is from QEDS and WDI databases of World } \\
\text { Bank. Reserves are foreign reserves less gold and are from IFS, } \\
\text { as is nominal GDP. }\end{array}$ \\
\hline $\begin{array}{l}\text { (Short Term External Debt - } \\
\text { Reserves)/GDP, \% }\end{array}$ & $\begin{array}{l}\text { Short term external debt is from QEDS and WDI databases of } \\
\text { World Bank. Reserves are foreign reserves less gold and are } \\
\text { from IFS, as is nominal GDP. }\end{array}$ \\
\hline Banking Crisis & Reinhart and Rogoff (2011) \\
\hline Inflation Crisis & Annual inflation above 20 percent. Reinhart and Rogoff (2011) \\
\hline Flight & $\begin{array}{l}\text { A surge in residents' outflows abroad. Defined using gross } \\
\text { outflows data from IFS, using methodology described in Forbes } \\
\text { and Warnock (2011) }\end{array}$ \\
\hline Change in Stock Prices (\% yoy) & $\begin{array}{l}\text { Year on year percentage change in series "LOCNSH: Share } \\
\text { prices,Index, 2005=100" from IFS. }\end{array}$ \\
\hline \multicolumn{2}{|l|}{ Other Variables: } \\
\hline Capital Account Openness (Quinn) & $\begin{array}{l}\text { Higher values indicate greater de-jure capital account openness. } \\
\text { Source: Quinn (1997) and Quinn and Toyoda (2008) }\end{array}$ \\
\hline Capital Account Openness (Chinn-Ito) & $\begin{array}{l}\text { Higher values indicate greater de-jure capital account openness. } \\
\text { Source: Chinn and Ito (2010) }\end{array}$ \\
\hline Floating Exchange Rate Regime & $\begin{array}{l}\text { Dummy variable which takes the value } 1 \text { when the country had } \\
\text { "Freely Floating" exchange rate policy for more than half the } \\
\text { quarter. The exchange rate classification information and dates } \\
\text { of change are from IMF AREAER. }\end{array}$ \\
\hline IT Monetary Policy & $\begin{array}{l}\text { Dummy variable which takes the value } 1 \text { when the country had } \\
\text { Inflation Targeting monetary policy framework in more than } \\
\text { half the quarter. The IT frameworks information and dates of } \\
\text { change are from IMF AREAER. }\end{array}$ \\
\hline Net Easings of Inflows & $\begin{array}{l}\text { Number of net easings of inflow controls in the quarter by the } \\
\text { country. See Appendix A for details on data. }\end{array}$ \\
\hline Trade/GDP, \% & $\begin{array}{l}\text { (imports + exports) /nominal GDP, expressed as percentage. All } \\
\text { series are from Haver/National statistical databases. }\end{array}$ \\
\hline
\end{tabular}

